\title{
Türkiye'de Kentlere İlişkin Bazı Göstergelerin Öğrenci Başarısına Etkisinin Çok Değişkenli Doğrusal Regresyon ile Modellenmesi
}

\begin{abstract}
Öz
Bu çalışmada Türkiye'deki en yaygın merkezi sınav olan üniversiteye giriş sınavlarındaki başarıda, öğrencilerin yaşadığı yere ilişkin çeşitli göstergelerin etkisinin incelenmesi amaçlanmıştr. Çalışmada bağımlı değişken olarak öğrencilerin 2016 Lisans Yerleştirme Sınavlarındaki Türkçe-Matematik, Türkçe-Sosyal ve Matematik-Fen Puanları; bağımsız değişkenler olarak illerde Yaşam Endeksi değişkenleri ele alınmış ve çok değişkenli doğrusal regresyon analizi kullanılmıştır. Elde edilen bulgulara göre Türkçe-Matematik alanındaki başarı üzerinde yaşanan kente ilişkin eğitim, altyapı hizmetleri ve yaşam memnuniyeti değişkenlerinin istatistiksel olarak anlamlı bir etkisi vardır. Bu değişkenlerdeki değişim kentteki öğrencilerin ortalama puanlarındaki değişimin \% 70,2'sini açıklamaktadır. Türkçe-Sosyal alanındaki başarı üzerinde gelir ve servet, eğitim, altyapı hizmetleri değişkenlerinin istatistiksel olarak anlamlı bir etkisi vardır. Bu değişkenlerdeki değişim kentteki öğrencilerin ortalama puanlarındaki değişimin \% 62,1'ini açıklamaktadır. Matematik-Fen alanındaki başarı üzerinde ise eğitim değişkeninin istatistiksel olarak anlamlı etkisi vardır ve bu değişkendeki değişim öğrencilerin Matematik-Fen alanı puanlarındaki değişimin \% 55,1'ini açıklamaktadır.
\end{abstract}

Aygülen KARAKUL ${ }^{*}$

Anahtar Kelimeler: illerde Yaşam Endeksi, Öğrenci Başarısı, Çok Değişkenli Doğrusal Regresyon Analizi.

\section{Modelling of the Impact of Some Indicators about Cities in Turkey on Student Achievement by Multivariate Linear Regression Analysis}

\begin{abstract}
In this study it is aimed to examine the effects of some indicators about the city on the achievement of students in the entrance exams to universities which is the most proliferated central exam in Turkey. The dependent variable is the scores of students in Undergraduate Placement Exam-2016 in the fields of Turkish-Mathematics; Turkish-Social and Mathematics-Science. The independent variables are the variables in Life Indexes in Provinces. The multivariate linear regression analysis has been employed. According to findings, education, infrastructure and life satisfaction variables have a statistical meaningful impact on the success in the field of Turkish Mathematics. Change in these variables explains the $70,2 \%$ of change of the student achievement in the MathematicsTurkish branches in a city. Income and wealth, education, infrastructure services have statistically meaningful impact on the success of students in the Turkish Social branch. Change in these variables explains the $60,1 \%$ chance of the students achievement in the Turkish-Social branches in a city. Education has a statistically meaningful effect to the success of students in Mathematics-Science branches. Change in this variable explains the $55,1 \%$ of the change of students achievement in the Mathematics- Science branch.
\end{abstract}

Keywords: The Life Index in Provinces, Student Achievement, Multivariate Linear Regression Analysis.

Yrd. Doç. Dr. İzmir Kâtip Çelebi Üniversitesi, iktisadi ve İdari Bilimler Fakültesi, Sayısal Yöntemler Anabilim Dalı, aygulen.kayahan@ikc.edu.tr 


\section{Giriş}

Başarı, "Kişinin yetenek ve yetişmeye bağlı olarak gösterdiği ansal ya da eylemsel etkinliklerinin olumlu ürünü" olarak tanımlanabilir (TDK, 2016). Ayrıca önceden kararlaştırılmış bir görev ya da ölçüte göre bireyin yaptı̆̆ı iş ya da ürün olarak tanımlanabilir (Balcı, 2005). Başarı sayısal ya da sayısal olmayan göstergelerle ölçülür. Gündelik yaşamda en önemli başarı göstergesi olarak kullanılan okul başarısı okulların amaçlarına dönük olarak öğrenciye kazandırıması hedeflenen davranışları kazandırabilme düzeyi olarak ifade edilmekle birlikte pratikte sayısallaştııımış olan ölçütler kümesindeki hedeflere ulaşma düzeyine işaret eder. Okul başarısı aynı zamanda öğrencinin öğrenme durumunun gerçekleşmesi olarak ele alındığında öğrenci başarısı olarak ifade edilir.

Öğrenci başarısının ölçülmesi ve öğrenci başarısını etkileyen faktörlerin araştırıması eğitim bilimciler açısından uzun bir geçmişe dayanan bir sorunsaldır. Bu anlamda çeşitli öğrenme kuramları, modelleri ve yaklaşımları ortaya atılmış, öğrenmenin nasıl gerçekleştiği ve daha etkili bir şekilde gerçekleşmesi için neler yapılması gerektiği uzun çalışmalar sonrasında ortaya konmuştur. Tam Öğrenme Modeli, Programlı Öğrenme Modeli, Okulda Öğrenme Modeli, Probleme Dayalı Öğrenme Modeli, Yapılandırmacı Öğrenme Modeli, İşbirliğine Dayalı Öğrenme Modeli, Anlamlı Öğrenme Modeli, Bireyselleştirilmiş Öğrenme Modeli, Sosyal Öğrenme Modeli, Yaşantısal Öğrenme Modeli, Temel Öğretim Modeli, Öğrenme Stilleri Modeli, Kaynaştırma Yeteneği Modeli, Etkili Öğretim Modeli, Proje Tabanlı Öğrenme Modeli geliştirilmiştir (Taşpınar, 2012; Dağlı, 2014; Köksal ve Atalay, 2015).

Tüm bu modeller ve yaklaşımlar öğrenmenin ve öğretimin amaçlarına bağlı olarak nasıl gerçekleştiğini, öğrenme çıktlarının değerlendirilmesi aşamasındaki başarı göstergelerinin neler olduğunu, başarının arttırılması için neler yapılması gerektiğini içermektedir. Öğrenci başarısının ölçülmesindeki nihai amaç kontrol edilebilen girdi değişkenleri üzerinde değişiklik yapılarak başarının yükseltilmesidir.

Öğrenci başarısını etkileyen faktörlere ilişkin yapılan çalışmalarda ele alınan değişkenler sınıf mevcudu, sınıfin ve okulun fiziki özellikleri, öğretmenin nitelikleri ve yeterlikleri gibi eğitim sürecine ilişkin girdilerdir (Kurul, 2002). Girdi odaklı yapılan inceleme, girdilerin niteliğini arttırmak suretiyle başarının artacağı varsayımı ile araştırmacılara iyimser gelecek tahmini yapma şansı vermektedir. Benzer olarak eğitim politikalarına dönük hedeflerin belirlenmesinde girdilerin kalitesinin arttırılması ile sistemin toptan bir iyileşme sağlayacağı düşüncesi eğitim alanına devlet yatırımlarını arttırma anlayışını rasyonel olarak desteklemektedir.

\section{BAŞARI KAVRAMI}

Girdi odaklı yaklaşımda eğitim sistemi üretim fonksiyonu ile ifade edilebilen bir sistemdir. Üretim fonksiyonu girdiler ve çıktlar arasındaki iktisadi anlamdaki ilişkiyi ifade eder. Üretim fonksiyonu, (Ç) bağımlı değişken çıkt, (E) emek, (S) sermaye, (T) toprak olmak üzere

$\mathcal{C}=f(E, S, T)$

olarak ifade edilir (Parasız, 2014). Üretim fonksiyonunu eğitim sistemindeki başarı üzerine uyarlayınca da başarı fonksiyonu;

Başarı = $\mathrm{f}$ (Okul kaynakları, Aile özellikleri, Akran grubu özellikleri) 
olarak ifade edilebilir (Katzman, 1971'den Aktaran: Kurul, 2002: 41). Bu modelde okul kaynakları okula başlayan birey için kullanılan fiziki kaynakları, aile özellikleri kalıtımla gelen gizil güçleri, akran grubu özellikleri ise kişinin yaşamındaki akran gruplarının özelliklerini temsil etmektedir. Bu modele göre kontrol edilebilir ve iyileştirilebilir bir değişken olarak okul kaynaklarına yapılacak yatırımlar başarıyı arttıracaktır. Model, kısaca eğitime devlet yatırımlarının yapılmasının bir alt yapısını oluşturmuş, böylece temel eğitimin geniş kitlelere yaygınlaştrıımasına katkı sağlamıştır.

Ancak başarının bu iktisadi modelde görülenden daha fazla etkene bağlı olup olmadığı konusu gündeme gelmiştir. Özellikle 20.yüzyılın son çeyreğinde yapılan hem nicel hem de nitel araştırmalar başarının toplumsal köken, ailenin ekonomik altyapısı, cinsiyet ve diğer pek çok sosyal değişkenle kuvvetli ilişkisi olduğunu göstermektedir. Böylece okulları başarının yetenek ve motivasyona bağlı olduğu meritokratik kurumlar olarak mı, yoksa başarının sosyal sınıf, etnik köken ve okul dışı diğer sosyal değişkenlere bağlı olduğu kurumlar olarak mı görmek gerektiği sorgulanmaya başlamıştır.

Başarıda okul dışı değişkenlerin etkisi üzerine yapılan araştırmalar girdi odaklı yaklaşımın beraberinde getirdiği iyimserlik bakışını sarsmıştır. Girdilerin ekonomik pozisyonuna ilişkin bir düzenleme yapılmadığı sürece ya da sosyal değişkenlerin etkisini eşitleyici politikalar hayata geçirilmediği sürece, eğitim sistemi içindeki kalite arttırıcı çalışmaların ancak toplam başarıya etki edeceği, ancak başarılı olan kesimlerin hep aynı kesimlerden, başarısız olanların yine hemen hemen hep aynı kesimlerden olacağını ortaya koymuştur (Willis, 1977; Everheart, 1983; McRobbie,1978; Sayılan \& Özkazanç, 2008; Mclaren, 2003; Apple, 2006). Aynı zamanda bu araştırmalar, öğrenci başarısını arttırmak için asıl yapılacak olanın okul girdilerine yapılacak yatırımlar olmadığını göstermektedir. Bu durum her çocuk öğrenebilir gibi iyimser yaklaşımı altüst ettiği için, ana akım iktisat araçlarından üretim fonksiyonunun da içinde bulunduğu eğitimsel girdilerin öğrenmedeki rolüne ilişkin inancı sarsmış, başarıda sosyal değişkenlerin rolünün ne olduğunun, başarıyı arttırmak için bu sosyal değişkenlerle ilgili ne gibi eğitim politikalarının geliştirilmesi gerektiğinin yeniden düşünülmesini sağlamıştır.

Bugün öğrenci başarısı notlar, karneler, takdir ve teşekkür belgelerinin yanı sıra 12 yıllık eğitim sisteminin sonunda yapılan üniversiteye giriş sınavları ile de belirlenmektedir. Bu sınavlar aslında üniversitedeki başarının yordayıcısı olarak yapılmakta ancak bir yandan da geçmiş eğitim sistemi içindeki başarının göstergesi olarak ele alınabilmektedir.

\section{BAŞARI GÖSTERGESI OLARAK LISANS YERLEŞTIRME SINAVLARI}

Türkiye'de üniversiteye giriş sınavları 2010-2017 yılları arasında her yılın üçüncü ya da dördüncü aylarında birinci basamak, altıncı ayında ise ikinci basamak olmak üzere iki basamaklı olarak yapılmıştır. Birinci basamak sınavı Yükseköğretime Geçiş Sınavı (YGS) ismini taşımaktadır ve tek oturumda gerçekleştirilmiştir. İkinci basamak sınavı ise Lisans Yerleştirme Sınavı (LYS ) ismini taşımaktadır ve iki hafta sonunda toplamda 4 günde, 5 oturumda gerçekleştirilmiştir. YGS'den önceden belirlenen baraj puanının üstünde puan alan öğrenciler LYS'ye girebilmekte ve girmek istedikleri üniversite bölümünün öğrenci aldığı puan türüne göre beş farklı oturumdan hangilerine gireceklerine kendileri karar vermektedir.

Üniversiteler ise Türkçe Matematik (TM), Türkçe Sosyal (TS), Matematik Fen (MF) veya 
Yabancı Dil Alanı olarak dört puan türüne göre öğrenci seçmekte, dolayısıyla LYS sınavlarının herhangi bir oturumundan birine giren her öğrencinin TM, TS veya MF puan türlerine göre puanı hesaplanmaktadır. Yabancı Dil Puanı ise sadece Yabancı Dil Alanından sınava giren öğrenciler için hesaplanmaktadır.

Çizelge1'de 2013-2016 yılları arasındaki LYS'ye katılan öğrencilerin TM, TS ve MF puan türlerindeki ortalamaları verilmiştir.

\section{Çizelge 1: Öğrencilerin LYS Puan Ortalamalarının Yıllara ve Puan Türlerine Göre} Dağılımı

$\begin{array}{llll} & \text { TM } & \text { TS } & \text { MF } \\ 2013 & 244,463 & 248,68 & 244,25 \\ 2014 & 233,792 & 242,33 & 236,015 \\ 2015 & 232,099 & 245,359 & 230,017 \\ 2016 & 219,415 & 215,343 & 208,652 \\ \text { Kaynak: OSYM, 2013a; OSYM, 2014a; OSYM, 2015a; OSYM, 2016a } & \end{array}$

Çizelge 1'e göre 2016 yılında TM, TS ve MF türümdeki LYS puanları son dört yılın en düşük ortalamasına sahip olmuştur. Her yıl gerek YGS sonuçları açıklandığında gerekse LYS sonuçları açıklandığında özellikle her alandan birincilerle birlikte sınavda derece yapan öğrenciler medyada yer almakta, hangi şehirden, hangi tür okuldan yetiştikleri, ailelerinin meslekleri ve benzeri özel bilgilerinin yanı sıra, başarıya ulaşmak için neler yaptıkları da medyada gündem konusu olmaktadır.

Bireysel başarı göstergesi olarak ele alınabilen üniversiteye giriş sınavları için aynı zamanda iller arası bir kıyas da yapılmakta ortalamada en yüksek puan alan iller ile en düşük puan alan iller gündeme gelmekte, kentler de başarılı veya başarısız olarak gruplanabilmektedir. Çizelge-2 de sırasıyla 2013-2016 yılları arasında yapılan LYS'lere göre TM, TS ve MF puanlarında ortalaması en yüksek ve en düşük olan 5 il verilmiştir.

Çizelge 2: Yıllara Göre LYS Puanları Ortalaması En Yüksek ve En Düşük iller 2013

$\begin{array}{llllll}\text { TM } & & \text { TS } & & \text { MF } & \\ \text { En Yüksek } & \text { En Düşük } & \text { En Yüksek } & \text { En Düşük } & \text { En Yüksek } & \text { En Düşük } \\ \text { Kilis } & \text { Ardahan } & \text { Bartn } & \text { Hatay } & \text { Karabük } & \text { Hakkâri } \\ \text { Ankara } & \text { Hakkâri } & \text { Ardahan } & \text { Hakkâri } & \text { Kırşehir } & \text { Van } \\ \text { Isparta } & \text { Batman } & \text { Bilecik } & \text { Van } & \text { Eskişehir } & \text { Ağrı } \\ \text { Kırıkkale } & \text { Şırnak } & \text { Bolu } & \text { Adıyaman } & \text { Isparta } & \text { Şırnak } \\ \text { Bartın } & \text { Van } & \text { Sinop } & \text { Tunceli } & \text { Ankara } & \text { Ardahan } \\ \mathbf{2 0 1 4} & & & & & \\ \text { TM } & & \text { TS } & & \text { MF } & \\ \text { En Yüksek } & \text { En Düşük } & \text { En Yüksek } & \text { En Düşük } & \text { En Yüksek } & \text { En Düşük } \\ \text { Kilis } & \text { Hakkâri } & \text { Kastamonu } & \text { Hakkâri } & \text { Karabük } & \text { Hakkâri } \\ \text { Ankara } & \text { Ardahan } & \text { Bartın } & \text { Osmaniye } & \text { Yalova } & \text { Ardahan } \\ \text { Burdur } & \text { Ağrı } & \text { Edirne } & \text { Şırnak } & \text { Isparta } & \text { Ağrı } \\ \text { Kırıkkale } & \text { Mardin } & \text { Bilecik } & \text { Batman } & \text { Eskişehir } & \text { Artvin } \\ \text { Kırşehir } & \text { Muş } & \text { Denizli } & \text { Hatay } & \text { Burdur } & \text { Van }\end{array}$




\begin{tabular}{llllll} 
2015 & & & & \\
TM & & TS & MF & \\
En Yüksek & En Düşük & En Yüksek & En Düşük & En Yüksek & En Düşük \\
Burdur & Hakkâri & Edirne & Hakkâri & Kırşehir & Hakkâri \\
Bilecik & Şırnak & Eskişehir & Ardahan & Bilecik & Şırnak \\
Bingöl & Ardahan & İstanbul & Şırnak & Bingöl & Yalova \\
Kütahya & Batman & Bursa & Muş & Denizli & Kars \\
Sinop & Mardin & İzmir & Mardin & Bayburt & Ardahan \\
2016 & & & & & \\
TM & & TS & & MF & \\
En Yüksek & En Düşük & En Yüksek & En Düşük & En Yüksek & En Düşük \\
Burdur & Mardin & Edirne & Mardin & Bayburt & Mardin \\
Niğde & Batman & Eskişehir & Muş & Kırşehir & Kars \\
Bilecik & Ardahan & Niğde & Şırnak & Niğde & Şırnak \\
Kütahya & Şırnak & İstanbul & Ardahan & Bilecik & Hakkâri \\
Sinop & Hakkâri & Bursa & Hakkâri & Denizli & Ardahan \\
\hline
\end{tabular}

Kaynak: OSYM, 2013b; OSYM,2014b; OSYM, 2015b; OSYM, $2016 b$.

Çizelge 2'ye göre genellikle üç puan türünde de ortalaması en düşük kentler benzerlik göstermekte, Doğu ve Güney Doğu Anadolu bölgesinden illeri içermektedir. Ortalaması en yüksek iller de benzerlik göstermekte, Doğu ve Güney Doğu Anadolu bölgesi dışından illeri içermektedir. Bu durum başarıda yaşanan ilin bulunduğu coğrafi bölgenin özelliklerinin, bu ile ilişkin çeşitli değişkenlerin etkisinin olup olmadığını gündeme getirmektedir.

\section{3. ÍLLERDE YAŞAM ENDEKSI}

Türkiye'de ilk defa 2015 yılında iller arasında bir karşılaştırma yapabilmek ve farklı değişkenlere göre illeri sıralayabilmek için Tüik tarafindan Illerde Yaşam Endeksi çalışmaSı yapılmıştır. OECD’nin yaptı̆̆ ve ülkelerarası bir karşılaştırmayı içeren Daha İyi Yaşam Endeksi baz alınarak Türkiye'deki iller arasında bir karşılaştırmayı içeren illerde Yaşam Endeksi çalışmasının sonuçları 2016 yılında kamuoyu ile paylaşılmıştı (TÜiK, 2016). Çaış̧madaki genel amaçlar birey, hanehalkı ve sonuç odaklı, "o ilde" yaşayanların yaşam düzeyini ölçmeye ve zaman içinde izlemeye olanak sağlayan, iyi yaşamı oluşturan alt boyutları tek bir boyuta indirgeyen bileşik bir endeks elde etmektir (TÜiK, 2016).

Genel olarak ülkelerin, bölgelerin karşılaştrılmasında kullanılan bileşik endekslerin hesaplanmasında gösterge değişkenlerinin normalleştirilmesi, ağılıklandırılması ve toplulaştrılması aşamaları bulunmakta olup Tüik illerde Yaşam Endeksi'ni hesaplarken normalleştirme aşamasında göstergelerin $(0,1)$ aralığında normalize eden min-maks yöntemini kullanılmıştır.

Endekse katkı yönü negatif olan (işsizlik oranı, cinayet oranı gibi) göstergeler endeks hesabına ters kodlanmış olarak katılmıştı (TÜiK, 2016). TÜiK tarafindan gerçekleştirilen tüm bu işlemler sonucunda elde edilen bileşik endekse göre Türkiye'deki illerde Yaşam Endeksi sıralaması Çizelge 3'de verilmiştir: 
Çizelge 3: Illerde Yaşam Endeksine Göre IIllerin Sıra Değerleri

\begin{tabular}{|c|c|c|c|c|c|}
\hline il & Siralama & il & Siralama & il & Siralama \\
\hline Isparta & 1 & Kırşehir & 28 & Ordu & 55 \\
\hline Sakarya & 2 & Giresun & 29 & Çorum & 56 \\
\hline Bolu & 3 & Tekirdağ & 30 & Yozgat & 57 \\
\hline Kütahya & 4 & Manisa & 31 & Elazığ & 58 \\
\hline İstanbul & 5 & Kırklareli & 32 & Mersin & 59 \\
\hline Uşak & 6 & Samsun & 33 & Gaziantep & 60 \\
\hline Balıkesir & 7 & Erzincan & 34 & Adana & 61 \\
\hline Artvin & 8 & Edirne & 35 & Tunceli & 62 \\
\hline Kırıkkale & 9 & Kastamonu & 36 & Bingöl & 63 \\
\hline Afyonkarahisar & 10 & Nevşehir & 37 & Hatay & 64 \\
\hline Sinop & 11 & Bartin & 38 & Siirt & 65 \\
\hline Karabük & 12 & Tokat & 39 & Osmaniye & 66 \\
\hline Bilecik & 13 & Sivas & 40 & Kilis & 67 \\
\hline Rize & 14 & Zonguldak & 41 & Bitlis & 68 \\
\hline Eskişehir & 15 & Kayseri & 42 & Adıyaman & 69 \\
\hline Yalova & 16 & Burdur & 43 & Kars & 70 \\
\hline Ankara & 17 & Antalya & 44 & Van & 71 \\
\hline Konya & 18 & Muğla & 45 & Iğdır & 72 \\
\hline Bursa & 19 & Aydın & 46 & Şanlıurfa & 73 \\
\hline Trabzon & 20 & Bayburt & 47 & Ardahan & 74 \\
\hline İzmir & 21 & Kahramanmaraş & 48 & Diyarbakır & 75 \\
\hline Çankırı & 22 & Düzce & 49 & Hakkari & 76 \\
\hline Kocaeli & 23 & Gümüşhane & 50 & Batman & 77 \\
\hline Çanakkale & 24 & Niğde & 51 & Şırnak & 78 \\
\hline Karaman & 25 & Erzurum & 52 & Ağrı & 79 \\
\hline Denizli & 26 & Malatya & 53 & Mardin & 80 \\
\hline Amasya & 27 & Aksaray & 54 & Muş & 81 \\
\hline
\end{tabular}

Kaynak: TÜiK, 2016

Çizelge 3'te verilen, sıralamaya bakılırsa ilk 5'te yer alan iller Isparta, Sakarya, Bolu, Kütahya ve İstanbul olmak üzere genellikle bat illeridir. Son 5 sırada yer alan iller ise Batman, Şırnak, Ağrı, Mardin ve Muş olmak üzere Doğu ve Güneydoğu Anadolu illeridir. Bu durum son dört yılın LYS puan ortalamalarının verildiği Çizelge 2 ile paralellik göstermektedir. Dolayısıyla öğrenci başarısı üzerinde yaşanan yere ilişkin çeşitli sosyal değişkenlerin etkisi olup olmadığı konusu araştırılmalıdır. 


\section{LITERATÜR TARAMASI}

Öğrenci başarısını etkileyen değişkenleri betimlemeyi amaçlayan araştırmalarda ele alınan değişkenleri okul içi ve okul dışı değişkenler olarak gruplamak mümkündür. Okul içi değişkenler olarak çoğunlukla hazırbulunuşluk düzeyi, öğretmenlerin yeterlik durumları, eğitim öğretimde kullanılan yöntem ilke ve teknikler, öğrencilerin derslere, okula veya öğretmenlere dönük algıları ve tutumları, öğrenmeye ayrılan zaman, okul yöneticilerinin yönetim becerileri, devam edilen okulun türü gibi değişkenler ele alınmıştır. Okul dışı değişkenler ise ebeveynlerin eğitim durumu, ebeveynlerin gelir grubu, öğrencinin cinsiyeti, etnik kökeni, evde öğrenciye sağlanan olanaklar gibi sosyal değişkenler ele alınmıştır. Ancak öğrencilerin yaşadığı şehirlerin gelişmişlik düzeyinin ya da sosyo kültürel yapısının kentin ortalama öğrenci başarıya etkisine ilişkin bir çalışmaya literatürde rastlanmamıştır. Aksine, yaşanan yere ilişkin farklılıkların sonuçları etkilemesi istenmediğinden tabakalı örnekleme ya da amaçlı örnekleme yolu ile değişik yaşam alanlarından veriler elde edilerek araştırmalar gerçekleştirilmiştir. Dolayısıyla yaşanan yerin başarıya etkisi konusu başarıya etki eden sosyal değişkenler kümesi içinde ele alınmış ve literatür araştırması bu kapsamda gerçekleştirilmiştir.

\subsection{Başarıda Sosyal Değişkenlerin Etkisi Üzerine Yapılmış Nicel Araştırmalar}

20. yüzyılın ikinci yarısından itibaren okul başarısını etkileyen faktörlerin araştıııdığı pek çok çalışmada, ailenin sosyo ekonomik ve kültürel durumu, cinsiyet, etnik köken gibi sosyal değişkenlerin önemine odaklanılmıştı. Bu çalışmalardan ilki James Coleman'ın öğrenme ve başarıda değiştirilemez değişkenler olarak sınıfsal aidiyet ve aile kökeninin başarıya etkisine ilişkin yaptı̆̆ araştırmasıdır. Coleman (1966) ABD'de 600.000 öğrenciden elde ettiği verileri doğrusal regresyon yöntemi kullanarak analiz etmiş ve okulun niteliğiyle başarıyla ilgili ölçümler arasında neredeyse hiçbir ilişki olmadığını göstermiştir. Literatüre "Coleman Raporu" olarak geçen bu çalışmadan sonra alanda pekçok araştırmanın önü açılmıştır.

Jencks ve diğerleri (1973) yaptıkları araştırmada öğrencilerin başarıları üzerinde okullar arası farklılıkların değil, ailelerinin gelir düzeyleri arasındaki farklılıkların etkili olduğu sonucuna ulaşmıştır. Araştırmacılar yaş ve yaşanan bölge değişkenlerini kontrol altına alarak kullandıkları istatistiksel analiz yöntemleri sonucunda eğitimde firsat eşitliğini sağlamanın yolu olarak okullardaki girdileri düzenlemek yerine, toplumdaki gelir dengesizliğini gidermek gerektiği sonucunu elde etmişlerdir.

Heyneman ve Loxley (1983) tarafindan 29 gelişmiş ve az gelişmiş olan ülke üzerinde yapılan araştrrmada eğitimin ülke geliri ile istikrarlı ilişkisi ve gelir düştükçe okul kaynaklarının başarı üzerindeki etkisi ortaya konmuştur. Literatüre "Heyneman ve Loxley etkisi" olarak geçen araştırma sonuçlarına göre gelişmiş ülkelerde ailenin öğrenci başarısında çok etkisi olurken az gelişmiş ülkelerde ise öğrenci başarısında okulun etkisinin fazla olduğu elde edilmiştir.

Clark (1993) Los Angeles'daki 71 okulda, yüksek başarılı ve düşük başarılı olan 1.141 öğrenci üzerinde yaptığı araştırmasında öğrenci başarısındaki aile değişkeninin rolüne odaklanmış, başarılı öğrencilerin, onlara yüksek standartlar oluşturabilen ailelerden geldiğini göstermiştir. Araştırmasında düşük başarılı öğrencilerin ailelerinin çoğunlukla düşük gelirli, işsiz, üniversite mezunu olmayan, devletten sosyal yardım 
alan ve ikiden fazla çocuğu olan aileler olduğunu bulmuştur. Araştırmacının elde ettiği sonuçlara göre öğrenci başarısında aile içinde geçirilen süreçler, ebeveynlerin kişilik özellikleri ve ailenin gelir düzeyi, etnisitesi ve eğitim düzeyi gibi sosyoekonomik ve sosyo kültürel kimliği etkili olmaktadır.

Clark (2002) önceki araştırmasını (Clark, 1993) genişleterek ABD'deki 13 eyaletten 1.058 öğrenciden oluşan dokuz veri seti üzerinde öğrenci başarısında sosyal değişkenlerin rolüne odaklanmıştır. Yüksek başarılı öğrencilerin çoğunlukla okula daha çok gelebilen, okul dışındaki saatlerde daha çok hobiler edinme, birbirleri ile oyunlar oynama, konuşma, iletişim kurma gibi okul başarısına olumlu katkılar sağlayan etkinlikler yapabilen, daha çok uyuyabilen ve sağığını daha çok düşünebilen öğrenciler olduğunu bulmuştur. Buna karşın düşük başarılı öğrencilerin ise çoğunlukla "arkadaşlarla takılma", telefonla konuşma, televizyon izleme ve dinlenme, ev işleri yapma veya ücretli bir işte çalışma faaliyetlerini yapan öğrenciler olduğu sonucunu elde etmiştir. Bu sonuçlara göre de öğrenci başarısının öğrencinin okul dışında yaptı̆̆ı/yapabildiği sosyal alışkanlıklar ve etkinlikler gibi sosyal değişkenlere bağlı olduğu sonucunu elde etmiştir.

Hoffman, Llagas \& Snyder (2003: 62-64) araştırmalarında Afrikalı Amerikan öğrencilerle Beyaz öğrencilerin başarıları üzerine odaklanmışlardır. Amerika'daki üniversiteye giriş sınavı olarak kullanılan Scholastic Assesment Test (SAT) ve bu sınava benzer olan diğer bir seçim sınavı olan American College Testing (ACT)'deki farklı etnik gruplardan gelen öğrencilerin sınav başarılarını incelemişlerdir. 2001'de SAT'a giren öğrencilerin \% 66'sı beyazlardan, \% 11'i siyahlardan, \% 10'u Asyalı Amerikan öğrencilerden, \% 9'u Hsipaniklerden, \% 1'i Amerikan Hintlisi/Alaska yerlilerinden oluşmuştur. Siyah öğrenciler tüm etnik gruplara göre en az puanları elde etmiş, Hispanik öğrenciler de SAT'ın sözel ve matematik bölümlerinde en az puanları elde etmiştir. Ortalamada, siyah öğrenciler beyaz öğrencilere göre sözel bölümde 96 puan, matematik bölümünde 105 puan daha az almıştır. ACT'deki sonuçlar da benzer çıkmış, siyah öğrenciler ortalamada beyaz öğrencilere göre 16,9 puan daha az almışttr. $\mathrm{Bu}$ sonuçlar etnisitenin öğrenci başarısı üzerinde etkili olduğunu göstermektedir.

Yıldırım (2006) Ankara'da dershaneye devam eden 962 sekizinci, dokuzuncu, onuncu ve onbirinci sınıf öğrencisi üzerinde gerçekleştirdiği araştırmasında öğrenciler üzerinde anket çalışması yapmış, anket sonuçlarını manidarlık düzeyi 0,5 olacak şekilde Peaarson korelasyon katsayıları ve adımsal regresyon analizi tekniği kullanarak yorumlamıştır. Elde ettiği bulgulara göre aile içinde sıkıntı yaşamak, arkadaşlar arasında sıkıntı yaşamak, öğretim yaşamı ile ilgili sıkıntıları olmak, geniş çevrede sıkıntı yaşamak, aileden destek almak, arkadaşlardan destek almak ve öğretmenlerden destek almak ile cinsiyet değişkenlerinin öğrencilerin akademik başarılarının yordanmasında etkili olduğu sonucunu elde etmiştir.

Gelbal (2008) Türkiye'deki ilköğretim okullarından seçilen 30.714 öğrenciden oluşan bir örneklem üzerinde gerçekleştirdiği araştırmasında, sekizinci sınıf öğrencilerinin Türkçe dersi başarısındaki sosyoekonomik değişkenlerin etkisini belirlemeyi amaçlamıştr. Araştırma kapsamında hazırlanan bir Türkçe testi ve öğrencilerin demografik özelliklerinin ve görüşlerinin sorulduğu bir anket uygulanmış, veriler betimleyici ve yorumlayıcı istatistikler kullanılarak analiz edilmiştir. Cinsiyet, anne ve babanın eğitim düzeyi, kardeş sayısı ve 
evdeki olanakların Türkçe başarısı üzerindeki etkisi incelenmiştir. Evdeki olanaklar başlığı altında öğrencinin kendine ait çalışma odası, çalışma masası bulunup bulunmadığı, evde bilgisayar, internet bağlantısı olup olmadığı,telefon, televizyon ve televizyona bağlanan diğer aletler ile beyaz eşya olup olmadığı gibi ailenin sosyo ekonomik düzeyi hakkında bilgi veren sorular sorulmuştur. Elde edilen sonuçlara göre cinsiyetin, anne eğitim düzeyinin, evdeki olanakların ve kardeş sayısının öğrenci başarısı üzerinde etkili olduğu bulunmuştur.

Anıl (2009) Uluslararası Öğrenci Başarılarını Değerlendirme Programı́nda (PISA) Türkiye'deki öğrencilerin fen bilimleri alanlarındaki başarılarını etkileyen faktörleri belirlemeyi amaçladığı araştırmasında 15 yaş grubundaki 4.942 öğrenci üzerinde anket çalışması yapmıştır. Araştırma kapsamında öğrencilerin Fen Bilimleri başarıları üzerinde ebeveynlerin eğitim durumu, evde bilgisayar bulunup bulunmaması, ailenin kültür zenginliği değişkenlerinin etkisi belirlenmeye çalışılmıştr. Ailenin kültür zenginliği başlığı altında evde edebi eser, şiir kitapları ve yağlıboya tablo gibi sanat eserleri bulunup bulunmadığı gibi sorular sorulmuştur. Araştırma sonuçlarına göre öğrenci başarısını en çok babanın eğitim durumu etkilemekte ve başarıdaki değişimin \% 9'u babanın eğitim durumu ile açıklanmaktadır. Ayrıca Fen Bilimlerine karşı olumlu tutum, evde bilgisayar ortamına sahip olma, ailenin kültür zenginliği de başarıyı etkileyen faktörler olarak bulunmuştur.

Bahar (2010) Erzincan Üniversitesi Eğitim Fakültesine 2009-2010 öğretim yılında kayıtlı olan 274 dördüncü sınıf öğrencisi üzerinde gerçekleştirdiği araştırmasında öğrenci başarısında cinsiyetin, algılanan sosyal desteğin ve sosyometrik statünün etkisini belirlemeyi hedeflemiştir. Araştrrmadan elde ettiği verileri çok değişkenli doğrusal regresyon tekniği ile analiz etmiştir. Araştırma bulgularına göre cinsiyet, algılanan sosyal destek ve sosyometrik durum öğrenci başarısının \% 15'ini açıklamaktadır.

Pokropek, vd. (2015) sosyoekonomik eşitsizliklerin akademik başarı üzerindeki etkisini ortaya koymayı amaçladıkları çalışmalarında 2012 yılında 33 OECD ülkesinde uygulanan Uluslararası Öğrenci Başarılarını Değerlendirme Programı (PISA) kapsamında toplanan verileri kullanmışlardır. PISA'ya katlan öğrencilerin ailelerinin sosyoekonomik, kültürel ve öğrenme ile ilgili olabilecek diğer değişkenlerinin elde edildiği anket sonuçlarını doğrulayıcı faktör analizi ve yapısal eşitlik modeli kullanarak analiz etmişlerdir. Araştırmadan elde ettikleri sonuçlara göre ebeveynlerin meslekleri ile eğitim durumları eğitimsel kaynakların ve kültür varlıklarının evde daha çok bulunmasına etki etmektedir. Bu değişkenler ise ailenin eğitime dolaylı olarak katkı yapmasını sağlamaktadır. Dolayısıyla aile mesleği ile eğitim durumu matematik, okuma ve fen alanında öğrenci başarısını arttırmaktadır. Evde eğitim ile ilgili kaynaklara erişebilen öğrencilerin bu üç alanda da daha başarılı oldukları sonucu elde edilmiş, böylece ailenin sosyoekonomik ve sosyo kültürel durumunun öğrenci başarısında etkili olduğu görülmüştür.

Sarıer (2016) Türkiye'deki öğrencilerin akademik başarılarını etkileyen değişkenleri belirlemeyi amaçladığı araştırmasında, 2000-2015 yılları arasındaki 15 yıllık sürede Türkiye'de yapılmış olan 62 çalışmayı meta analiz yöntemi kullanarak analiz etmiştir. Araştırmasından elde ettiği sonuçlara göre öğrencilerin akademik anlamdaki başarılarını en çok etkileyen etmenlerin, öğrencinin ailesinin sosyo-ekonomik durumu, öğrencinin kendisinin yeterli olduğuna ilişkin olumlu düşünceleri ve başarmaya dönük istekliliği olduğunu elde etmiştir.

Sanjurjo vd. (2017) İspanya'daki iki dilli eğitim programındaki öğrencilerin fen alanın- 
daki başarıları üzerinde sosyal, kültürel ve ekonomik arkaplan değişkenlerinin etkisini araştırdıkları çalışmalarında 709 ilköğretim altıncı sınıf öğrencisinden oluşan ve amaçlı örnekleme yöntemi ile seçtikleri okullardaki öğrenciler üzerinde anket çalışması yapmışlardır. Sosyoenomik düzeylerini, ailedeki kültürel arkaplanı (evdeki kitap sayısı, kültürel aktivitelere katılım, başka ülkelere seyahat) değişkenlerini kullanarak öğrencileri düşük, orta ve yüksek sosyoekonomik köken olarak üç gruba ayırmışladır. Araştırma sonuçlarına göre sosyoekonomik düzeyi orta ve yüksek olan öğrencilerin ortalama başarısı diğer öğrencilerin başarısından yüksek olarak bulunmuştur.

\subsection{Başarıda Sosyal Değiş̧enlerin Etkisine Illişkin Yapılmış Nitel Araştırmalar}

20. yüzyılın ikinci yarısından itibaren başarıyı etkileyen sosyal değişkenlerin nicel yöntemler kullanılarak araştırılmaya başlanması, başarı kavramının kendisinin çoğunlukla sayısallaştırılmış göstergelerle ifade edilmesi ile ilişkilendirilebilir. Bu araştırmalar eğitim bilimciler için ufuk açıcı olmuş, başarıyı etkileyen pek çok sosyal değişken bu sayede ortaya çıkarılmış ve başarıyı artıcı eğitim politikalarının geliştirilmesine katkı sağlamıştır.

Öte yandan, bu araştırmalarla eş zamanlı olarak, başarının göstergesi olarak daha geniş bir ölçütler kümesi tanımlayarak başarının altında yatan etkenleri ortaya koyan pek çok nitel araştırma da yapılmıştır. Creswell'e (2003: 48) göre nitel araştırma bir problemi keşfetmek, nicel araştırmaları izlemek, nedensel teori ve modellerin bağlantılarıyla, mekanizmalarını açıklamak için kullanılır. Birbirini tamamlayıcı iki yöntem olarak ele alındığında başarıyı etkileyen sosyal değişkenleri açıklayan nicel araştırmaların alanda açtığı yeni ufukları kullanan nitel araştırmalar da burada anılmalıdır.

Bu nitel araşttrmalardan ilki Willis'in (1977) İngiltere'de bir sanayi bölgesi olan West Midlands kentinde alt sosyoekonomik düzeydeki erkek öğrencilerin 11 yaşından itibaren devam ettiği bir okulda gerçekleştirdiği etnografik çalışmasıdır. Bu çalışma eğitim sisteminin vaatlerinden biri olan sosyal tabakalar arasındaki mobilitenin çalışan sınıfların çocukları için neden gerçekleşmediğine odaklanmıştır. Araştırmadan elde edilen sonuçlara göre alt sosyoekonomik düzeydeki çocukların, müfredat dışı ancak okul içi pratiklerde aileden getirdikleri sosyal statüyü koruyacak rolleri edindiğini, okul içindeki pratiklerin bu rolleri pekiştirdiğini, öğretmenlerin, müfredatın ya da başka okul değişkenlerinin mobiliteyi sağlayıcı bir etkisi olmadığını bulmuştur. Dolayısıyla bu araştırma okul başarısının sosyal statü ile sıkı bağlarına dikkat çekmiştir.

McRobbie (1978), İngiltere'nin Birmigham kentinde benzer bir araştırma yürütmüş, yaşları 14 ile 16 arasında değişen ve aileleri genellikle düşük statülü işler yapan kız öğrencilerin bulunduğu bir gençlik klübünde etnografik bir araşttrma yürütmüştür. Öğrencilerin babaları genellikle işsiz, çalışıyorsa otomotiv sanayinde çalışan işçiler, anneleri ise genellikle işsiz, çalışıyorsa da part time temizlik işlerinde çalışan ya da garsonluk, sekreterlik yapan işçilerdir. McRobbie araştırmasında bu çocukların eğitim yolu ile sosyal tabakalar arasında geçiş yapamadığını, yani teoride okul başarısının yordayıcı bir değişkeni olan sosyal mobilitenin gerçekleşmediğini göstermiştir. Bizzat okul içindeki tüm pratiklerin bu geçiş yapamama durumunu pekiştirdiğini göstermiştir. Dolayısıyla bu araştırma da başarının sınıfsal köken ile bağlarına dikkat çekmektedir. 
Everheart (1983) ABD'deki bir ortaokulda katılımcı gözlem yolu ile gerçekleştirdiği çalışmasında öğretmenler tarafindan "tembel" olarak nitelenen ancak gündelik yaşamlarında okula devam etmenin yanısıra çeşitli ücretli işlerde çalışan "çalışkan" yoksul öğrencilerin okul yolu ile sosyal statülerinin değişmeyeceğinin farkında olduklarını belirtmiştir. Böylece bu farkındalık öğrenilmiş çaresizliğe dönüşmekte, okulda başarı elde edemeyen öğrenciler başarının sosyal statü ve sosyo ekonomik gelir düzeyi ile bağlarına örnek teşkil etmektedir.

Sayılan ve Özkazanç (2008) tarafindan Ankara'daki bir ortaöğretim okulunda beş ay süresinde gerçekleştirilen etnografik araştirmada, 20 kız ve 20 erkek öğrenci ile ve 15 öğretmen ile derinlemesine görüşme gerçekleştirmişlerdir. Araştırmacıların elde ettikleri bulgulara göre eğitimden beklentisi düşük olan yoksul öğrenciler okula, öğretmenlere ve okulda verilen değerlere karşı tepki duymaktadır, bu sebeple okulda başarıya odaklanmak yerine okul değerleri ile çatş̧macı bir role bürünerek, dersleri sabote etmek üzerine bir anlayış inşa etmişlerdir. Bu çalışmada başarının ya da başarısızlığın altında yatan etmenleri okulun orta sınıfların eril değerlerini öğrencilere kazandırma çabasının öğrencilerin sosyoekonomik gerçekliklerini değiştirici bir rolü olmaması gibi sosyal boyutlar altında gösterilmiştir.

McLaren'in (2003) ABD'de siyah ve yoksul öğrencilerin devam ettiği bir getto mahallesindeki okulda yaptığı öğretmenlik deneyimlerini paylaşthğı çalışması tipik bir etnografik araştırma olup, yoksul ve dezavantajlı kesimlerden gelen öğrencilerin okul başarısı elde edememeleri altında yatan etkenlere ışık tutmaktadır. Bu öğrenciler toplum içinde uğradıkları ayrımcılığın eğitim sisteminin içinde ve ondan geçtikten sonra ortadan kalkacağı varsayımının geçersiz olduğunu düşünmektedir ve okul yaşamları "başarı" ya odaklanarak değil okulun temsil ettiği değer ve vermeye çalıştğı sosyal rollere ve kimliklere karşı çıkarak, bu rol ve kimliklerin tersi yönünde davranışlar sergileyerek geçmektedir. Araştırmacı, çalışmasında öğrencilerin okullardaki bilginin sokaklarda hissedilen somut gerçek bilgiden farklı olduğunu deneyimledikçe okuldaki öğretilen bilginin pasif alıcıları olmayı reddettiklerini ortaya koymuş, böylece "başarısızlığın" altındaki etmenleri okulda verilen bilgilerin öğrencilerin gündelik yaşamdaki gereksinimlerini karşılamayacak olması nedeniyle öğrencilerin öğrenmeye karşı gösterdikleri direnç olarak belirlemiştir (McLaren, 2003).

Başarıya etki eden sosyal değişkenlerden birisi de yaşanılan yerdir. Yaşanılan yere yapılan devlet ve özel sektör yatırımları, kentteki insanların sivil toplum yaşamına katılım düzeyleri, mutluluk düzeyleri, algılanan ve gerçekte olan toplumsal cinsiyet eşitsizlikleri, etnik aidiyet durumları, kentin bulunduğu coğrafyanın özellikleri gibi pek çok değişken yaşanılan yerin betimlenmesinde kullanılabilir. Tüm bu değişkenlerin o kentteki insanların tercihlerine, tutumlarına ve davranışlarına, dünyaya, olaylara ve olgulara bakış açılarına etkisi vardır. Aynı zamanda da o kentteki yaşam kalitesi hakkında bilgi vermektedir.

\section{AMAÇ MODEL VE YÖNTEM}

\subsection{Araştırmanın Amacı}

Bu araştırmanın amacı okul başarısında yaşanan yerin etkisinin olup olmadığının varsa bu etkinin ne şekilde olduğunun belirlenmesidir. Okul başarısının göstergesi olarak üniversiteye giriş sınavında alınan puanlar ele alınmıştır. Yaşanan yeri betimleyici ölçüt 
olarak ise TÜiK tarafindan yapılan illerde Yaşam Endeksi göstergeleri ele alınmıştır. Bu göstergeler toplamda 41 alt göstergeden oluşan 11 başlık altında toplanmıştır. Bu başIıklar ise şunlardır: Konut, Çalışma Hayat, Gelir ve Servet, Sağlık, Eğitim, Çevre, Güvenlik, Sivil Katılım, Altyapı Hizmetlerine Erişim, Sosyal Yaşam, Yaşam memnuniyeti.

\subsection{Araştırmanın Modeli ve Yöntemi}

Bu çalışma ilişkisel tarama modelinde tasarlanmış olan bir araştırmadır. Tarama türünde gerçekleştirilen araştırmalarda ölçülen değişkenler arasındaki ilişkiler incelenebilmektedir (Büyüköztürk vd., 2013). iliş̧kisel tarama tipi araştırmalarda değişkenlerdeki değişimin ne kadarının diğer değişkenler tarafindan açıklanabileceği belirlenebilmektedir (Can, 2017: 12).

Çalışmada verilerin analizi çok değişkenli regresyon yöntemi kullanılarak gerçekleştirilmiştir. Çok değişkenli regresyon yöntemi bağımlı değişken ile bağımsız değişkenler arasındaki ilişkiyi matematiksel modellerle açıklayan değişkenler arasındaki karmaşık yapıyı tanımlayan, verileri özetleyen, bağımsız değişkenler yardımıyla bağımlı değişken değerini kestiren, "bağımsız değişkenlerden hangisi ya da hangilerinin bağımlı değişken değerini daha çok etkilediğini gösteren bir istatistiksel araştırma yöntemidir" (Alpar, 2011: 407).

k sayıda bağımsız değişkenin bağımlı değişken ile aralarındaki ilişki araştırılırken kurulan çok değişkenli doğrusal regresyon modeli aşağıdaki eşitlik 1'deki gibidir.

$$
y=\beta_{0}+\beta_{1} x_{1}+\beta_{2} x_{2}+\cdots+\beta_{k} x_{k}+\varepsilon
$$

Bu modelde $\beta_{j},(\mathrm{j}=0,1, \ldots, \mathrm{k}),(\mathrm{j}=0,1, \ldots, \mathrm{k})$ parametreleri regresyon katsayıları, ${ }^{x_{j}}$ bağımsız değişkenler, $\varepsilon$ hata terimi ve y de bağımlı değişkendir. Çok değişkenli regresyon analizinde tüm bağımsız değişkenlerin bağımlı değişken ile aralarındaki ilişkiler eşanlı olarak belirlenmektedir.

Kurulan modelin anlamlılığı t ve $\mathrm{F}$ testleri ile test edilir. Bu testlerde $\mathrm{H}_{0}$ hipotezi tüm regresyon katsayılarının sıfira eşit olması olarak kurulur. $\mathrm{H}_{1}$ hipotezi ise en az bir regresyon katsayısının sıfirdan farklı olması üzerine kurulur. Bu testteki hipotez aşağıdaki eşitlik 2 'de verilmiştir.

$\mathrm{H} 0: \beta_{1}=\beta_{2}=\cdots=\beta_{k}=0$ ve $\mathrm{H} 1: \beta_{j} \neq 0$

Bu test sonrası HO hipotezi kabul edilirse bağımlı değişken ile bağımsız değişkenler arasında doğrusal modelde bir ilişki olmadığı ya da bağımsız değişkenlerin bağımlı değişkendeki değişimi doğrusal modelde açıklayamadığı sonucu elde edilir. Eğer H1 hipotezi kabul edilirse bağımlı değişken ile bağımsız değişkenler arasında doğrusal modelde bir ilişki kurulabileceği kabul edilir ve regresyon katsayılarından en az birinin sıfirdan farklı olduğu sonucu elde edilir. Hangi regresyon katsayısının sıfirdan farklı olduğu test edilebilir. Bu kez kurulacak hipotezler ve t değeri aşağıdaki eşitlik 3'de verilmiştir

$$
\mathrm{HO}: \beta_{j}=0 \text { ve H1: } \beta_{j} \neq 0 \quad \mathrm{t}=\frac{\beta_{j}-\beta_{j}^{0}}{s \beta_{J}}
$$

(Burada ${ }^{S \beta_{J}}$ j. Regresyon katsayısına ilişkin standart hatadır. ) 
$\mathrm{Bu}$ test sonucunda eğer $\mathrm{HO}$ hipotezi kabul edilirse ilgili regresyon katsayısının modele katkısının önemli olmadığı ve istenirse modelden çıkarılabileceği söylenebilir. H1 hipotezi kabul edilirse ilgili değişkenin regresyon modeline yapacağı katkının anlamlı olduğu söylenir. F testi ile modeldeki tüm bağımsız değişkenlerin eş anlı olarak bağımlı değişkendeki değişimi açıklayabilip açıklayamadığını yani modelin bütünsel olarak anlamlılığı ölçülür. $\mathrm{F}$ testleri ve $\mathrm{t}$ testleri sonrası bulunan $\mathrm{F}$ ve $\mathrm{t}$ istatistiklerinin büyüklüklerine bakarak hangi değişkenlerin modele daha fazla katkı yaptı̆̆ konusunda bir yorum elde edilebilir (Montgomery vd., 2013: 84-90).

Her parametrenin üstünün "1" olduğu, parametrelerin modellerde üs olarak yer almadığı ve parametrelerin diğer parametrelerle çarpılıp bölünmediği modeller doğrusal regresyon modelleri olarak adlandırılmakta, bu şekilde ifade edilemeyen modeller için ise doğrusallaştırmayı sağlayan dönüşümler uygulanır. Birçok regresyon modeli grafiksel olarak bir eğri belirtse de bu tanıma göre model olarak doğrusal bir yapıya örnek teşkil eder. Doğrusal olmayan ilişkiler ise değişkenler üzerinde çeşitli dönüşümler yapılarak doğrusallaştrılabilir (Alpar, 2011: 439-441). Değişkenler üzerinde dönüşüm yapma verileri farklı birimlerle yeniden ifade etme işlemidir (Mertler ve Vannatta, 2005).

Çok değişkenli regresyon analizlerinde bağımsız değişkenler arasında güçlü ilişkilerin olması modelin açıklayıcılık etkisini düşürmekte, bu tür ilişkiler varsa bunu giderici yollar uygulanmalıdır (Çokluk vd., 2016: 35). Bu tür ilişkilere çoklubağlant problemi adı verilmektedir. Çoklu bağlantının olup olmadığının tespiti için Varyans Patlama Faktörünün (Variance Inflation Factor, VIF) ve Koşul İndeksinin(Condition Index-CI) hesaplanması ve önerilen alt sınır değerleri ile karşılaştırılması gerekmektedir (Tabachnick ve Fidel, 2013). Çok değişkenli regresyon analizlerinde çoklu bağlantı probleminin oluşması için VIF değerlerinin alt sınırı 10'dur (Tabachnick ve Fidel, 2013; Alpar, 2011; Çokluk vd., 2016). Çoklu bağlant probleminin olup olmadığının tespiti için uygulanan diğer bir yöntem bağımsız değişkenlerin korelasyon matrisine ilişkin öz değerlerin incelenmesi ile elde edilen Koşul İndeksinin hesaplanmasıdır. Çoklu bağlantı probleminin varlığı için Koşul İndeksinin alt sınırının 30 olması gerekmekte, değeri 30'un üzerinde olan koşul indeksi sayısı kadar bağımsız değişken arasında çoklu bağlantılı olma problemi oluşmaktadır (Tabachnick ve Fidel, 2013; Alpar, 2011; Çokluk vd., 2016).

Bu çalışmanın HO hipotezi çalışmada ele alınan değişkenler arasında doğrusal modelde bir ilişki olmadığı yani tüm regresyon katsayılarının 0 olduğu olarak kurulmuş, H1 hipotezi ise bağımsız değişkenler arasında doğrusal modelde bir ilişki olduğu şeklinde kurulmuştur. Çalışmada elde edilen verilerin analizinde SPSS 24 Paket programı kullanılmıştır. Analizler sonucu elde edilen $p$ değerlerinin 0.05 'den küçük olması bağımlı ve bağımsız değişkenler arasında kurulmuş olan doğrusal ilişkilerin istatistiksel olarak anlamlı olduğunu ifade etmektedir.

\section{BULGULAR}

Çalışmadaki analizler TM (Türkçe-Matematik), TS (Türkçe-Sosyal) ve MF (MatematikFen) alanlarında sınava girmiş olan öğrencilerin LYS puanları için ayrı ayrı gerçekleştirilmiştir. Şehirlere göre farklılık gösteren Illlerde Yaşam Endeksi değerleri 81 il için ele alınmıştır. Analizlerde 11 değişkenden 7 değişkenin bağımlı değişken üzerinde istatistiksel olarak anlamlı bir doğrusal model oluşturacak etkisinin olmadığı sonucuna ulaşılmıştır ve anlamlı etkisi olduğu görülen 4 bağımsız değişken ile analize devam edilmiştir. Bu dört 
bağımsız değişken Eğitim Hizmetleri, Altyapı Hizmetleri, Yaşam Memnuniyeti, Gelir ve Servet değişkenleridir. Bağımlı ve bağımsız değişkenler arasında doğrusal ilişkilerin kurulabilmesi için bazı değişkenlere 1 sayısı toplanarak 10 tabanına göre logaritması alınmıştr. Logaritmik dönüşümlerde her bir veriye 1 sayısının toplanması sıfirın logaritmasının tanımsız olması; ve 0 le 1 arasındaki sayıların logaritmalarının negatif olması nedeniyle gereklidir (Menard, 2010:13; Tabachnich ve Fidel, 2013). Çok değişkenli doğrusal modellerdeki ilişkiler eşitlik 4, 5 ve 6'da verilmiştir.

$\log (T M$ puanı $)=2.302+0.256 \log (1+$ eğitim endeksi $)+0.061 \log (1+a$ tyapı hizmetleri endeksi)+0.038log(1+yasam memnuniyeti endeksi) $(R 2=0,702)$

$\log ($ TS puanı $)=2.368+0.028$ (Gelir ve servet endeksi)+0,019(Eğitim endeksi)+ $0.012 \log$ ( Altyapı hizmetleri endeksi) $(R 2=0,621)$

$\log ($ MF puanı $)=2.304+0.346 \log (1+e g ̆$ itim endeksi $)(R 2=0,551)$

Eşitlik 4'e göre TM puanları üzerinde eğitim, altyapı hizmetleri ve yaşam memnuniyeti değişkenlerinin pozitif yönlü etkisi vardır. Katsayılar incelenirse en çok etkisi olanın eğitim değişkeni olduğu, sonrasında altyapı hizmetleri değişkeni olduğu görülmektedir. En az etkisi olan ise yaşam memnuniyeti değişkenidir. Ayrıca eğitim, altyapı hizmetleri ve yaşam memnuniyetindeki değişim öğrencilerin TM alanındaki başarılarındaki değişimin $\% 70,2$ 'sini açıklamaktadır.

Eşitlik 5'e göre TS puanları üzerinde gelir, eğitim ve altyapı hizmetleri değişkenleri pozitif yönlü etkiye sahiptir. Katsayılar incelenirse en çok etkisi olanın eğitim değişkeni olduğu, sonrasında gelir ve servet değişkeni olduğu görülmektedir. En az etkisi olan ise altyapı hizmetleri endeksi değişkenidir. Gelir-servet, eğitim ve altyapı hizmetlerindeki değişim öğrencilerin TS alanındaki başarılarındaki değişimin \% 62,1'ini açıklamaktadır.

Eşitlik 6'ya göre MF puanları üzerinde sadece eğitim değişkeninin pozitif yönlü bir etkisi vardır. Eğitim değişkenindeki değişim öğrencilerin MF alanı başarılarındaki değişimin \% $55,1^{\prime}$ ini açıklamaktadır.

Aşağıdaki Şekil 1, Şekil 2 ve Şekil 3'te yukarıdaki eşitliklerden tahmin edilen LYS puanları ile gerçek LYS Puanları aralarındaki uyum gösterilmiştir.

Şekil1: LYS-TM Puanlarının Tahmin Edilen Değerleri ile Gerçek Değerleri Arasındaki ilişskiler 


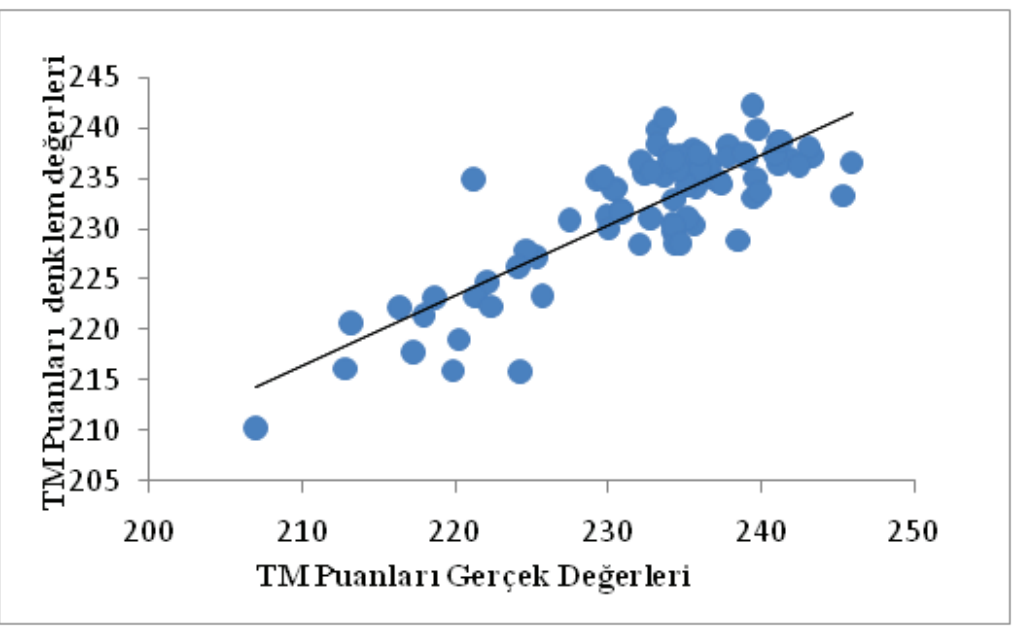

Şekil 2: LYS-TS Puanlarının Tahmin Edilen Değerleri ile Gerçek Değerleri Arasındaki ilişkiler

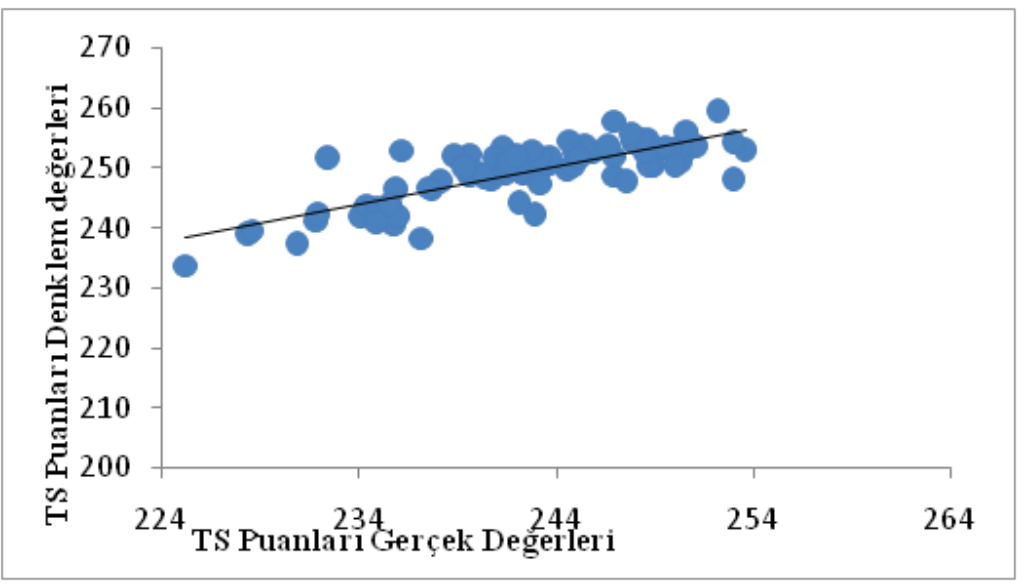

Şekil 3: LYS-MF Puanlarının Tahmin Edilen Değerleri ile Gerçek Değerleri Arasındaki ilişkiler 


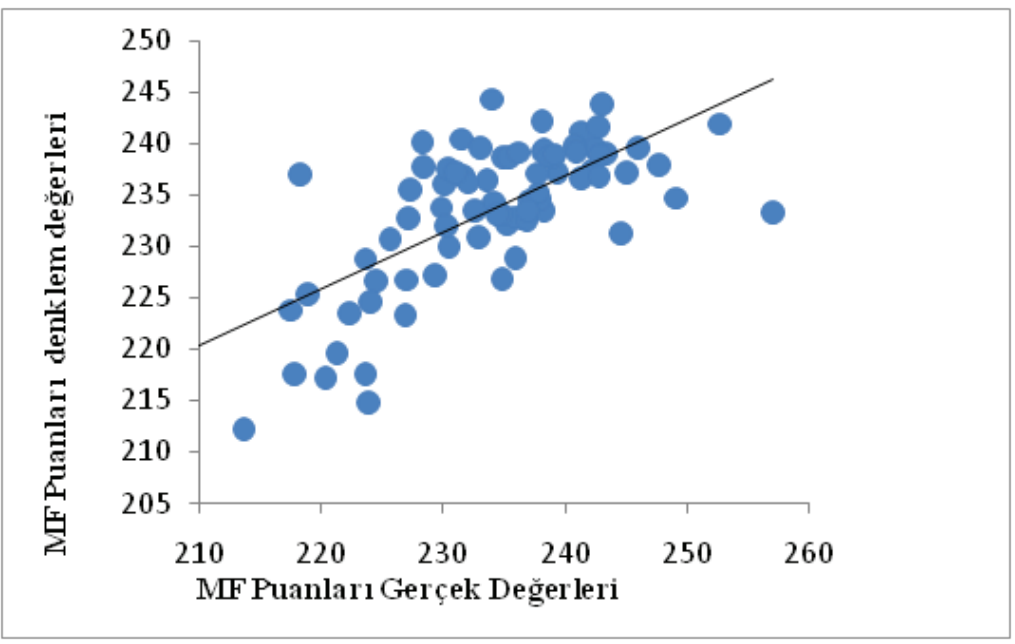

Şekil 1, Şekil 2 ve Şekil 3’ten görüleceği gibi çok değişkenli regresyon analizi ile elde edilen eşitliklerle tahmin edilen LYS puanları ile gerçek LYS puanları arasında iyi bir uyum vardır ve çok değişkenli analizlerle elde edilen kestirim eşitliklerinin kestirim performansı yüksektir.

Eşitlik (4) , (5) ve (6) da verilen ilişkilerdeki regresyon katsayılarının önemlilik dereceleri $\alpha=0,05$ önem düzeyinde $t$ ve $F$ testleri ile incelenmiştir. Bu testler çok değişkenli regresyon analizinin bir parçasıdır. Yapılan t testine ilişkin sonuçlar her bir puan türü için Çizelge 4'te verilmiştir.

\section{Çizelge 4: Regresyon Modellerinin t testi Sonuçları}

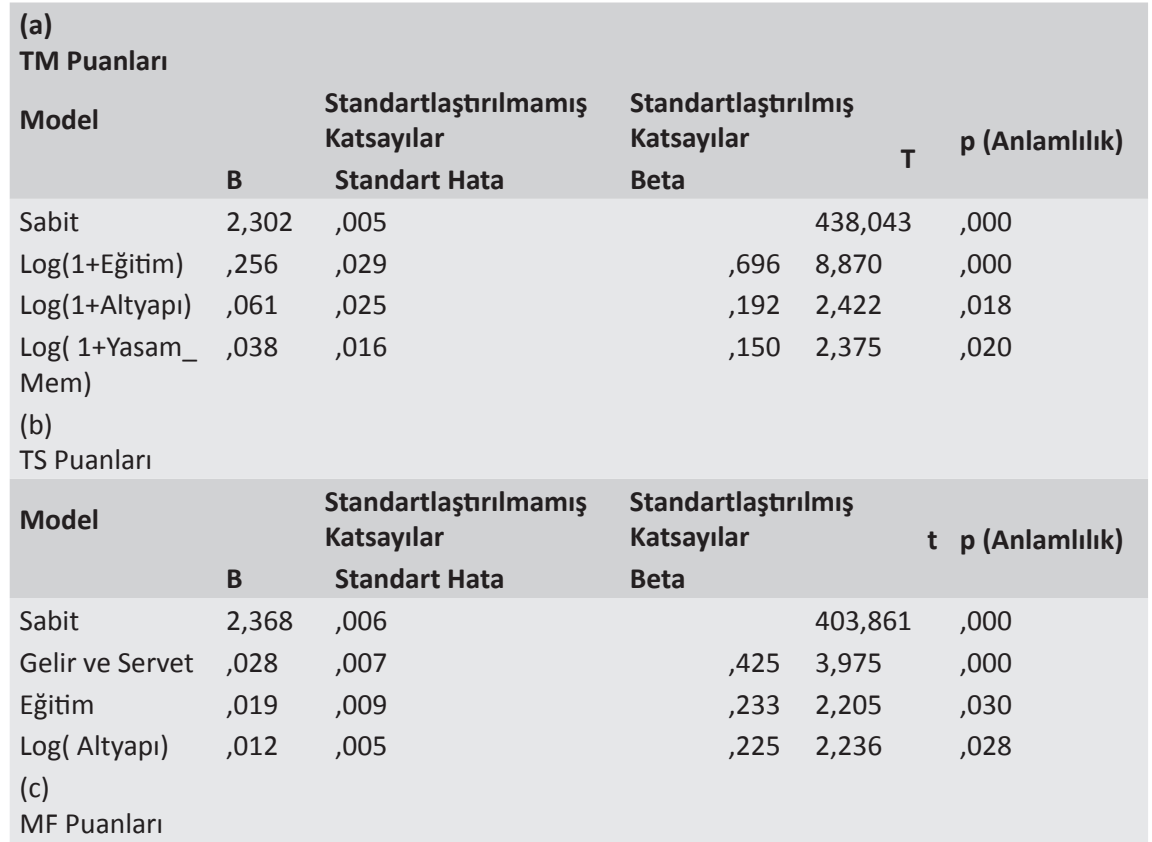




\section{Uluslararası Sosyal Bilimler Dergisi}

\begin{tabular}{|c|c|c|c|c|c|}
\hline \multirow[t]{2}{*}{ Model } & \multirow[b]{2}{*}{ B } & \multirow{2}{*}{$\begin{array}{l}\text { Standartlaştırılmamış } \\
\text { Katsayılar } \\
\text { Standart Hata }\end{array}$} & \multicolumn{2}{|c|}{$\begin{array}{l}\text { Standartlaştırılmış } \\
\text { Katsayılar }\end{array}$} & \multirow[t]{2}{*}{ t p(Anlamlılık) } \\
\hline & & & Beta & & \\
\hline Sabit & 2,304 & ,007 & & 348,879 & ,000 \\
\hline Eğitim & 346 & ,035 & ,742 & 9,845 & ,000 \\
\hline
\end{tabular}

Çizelge 4'ten görüleceği gibi regresyon analizindeki t değerleri için elde edilen anlamlıık düzeyleri $\alpha=0,05$ hata düzeyinden küçüktür. Bu nedenle TM, TS ve MF puanlarının kestirimi için kurulan çok değişkenli görgül ilişkilerdeki regresyon katsayıları sıfirdan farklı olup bağımlı değişkenle bağımsız değişkenler arasında doğrusal ilişkilerin var olduğu anlaşılmaktadır.

Modelin genel olarak anlamlılığıyla ilgili olarak tüm bağımsız değişkenlerin bağımlı değişkenle doğrusal bir ilişkiye sahip olup olmadığının değerlendirildiği $F$ testi sonuçları Çizelge 5'te verilmiştir.

Çizelge 5: Regresyon Modellerinin F testi Sonuçları

\begin{tabular}{|c|c|c|c|c|c|}
\hline \multicolumn{6}{|l|}{ (a) } \\
\hline \multicolumn{6}{|l|}{ TM Puanları } \\
\hline Model & $\begin{array}{l}\text { Kareler } \\
\text { Toplamı }\end{array}$ & $\begin{array}{l}\text { Serbestlik } \\
\text { Derecesi }\end{array}$ & $\begin{array}{l}\text { Kareler } \\
\text { Ortalaması }\end{array}$ & $\mathbf{F}$ & p (Anlamlılık) \\
\hline Regresyon & ,013 & 3 & , 004 & 60,509 & ,000 \\
\hline Artik & ,006 & 77 & ,000 & & \\
\hline Toplam & , 019 & 80 & & & \\
\hline \multicolumn{6}{|l|}{ (b) } \\
\hline \multicolumn{6}{|l|}{ TS Puanları } \\
\hline Model & $\begin{array}{l}\text { Kareler } \\
\text { Toplamı }\end{array}$ & $\begin{array}{l}\text { Serbestlik } \\
\text { Derecesi }\end{array}$ & $\begin{array}{l}\text { Kareler } \\
\text { Ortalaması }\end{array}$ & $\mathbf{F}$ & p (Anlamlılık) \\
\hline Regresyon & ,006 & 3 & , 002 & 42,117 & ,000 \\
\hline Artik & ,004 & 77 & ,000 & & \\
\hline Toplam & ,010 & 80 & & & \\
\hline \multirow{2}{*}{\multicolumn{6}{|c|}{$\begin{array}{l}\text { (c) } \\
\text { MF Puanları }\end{array}$}} \\
\hline & & & & & \\
\hline Model & $\begin{array}{l}\text { Kareler } \\
\text { Toplamı }\end{array}$ & $\begin{array}{l}\text { Serbestlik } \\
\text { Derecesi }\end{array}$ & $\begin{array}{l}\text { Kareler } \\
\text { Ortalaması }\end{array}$ & $\mathbf{F}$ & p (Anlamlılık) \\
\hline Regresyon & ,016 & 1 & ,016 & 96,932 & ,000 \\
\hline Arttk & ,013 & 79 & ,000 & & \\
\hline Toplam & ,030 & 80 & & & \\
\hline
\end{tabular}

Çizelge 5'e göre TM, TS ve MF puanları için yapılan çok değişkenli doğrusal regresyon analizleri sonucu sırasıyla $F=60,509 ; F=42,117$ ve $F=96,932$ değerleri hesaplanmıştır. Bu $F$ değerleri için elde edilen anlamlılık düzeylerinin tümü $\alpha=0.05$ hata düzeyinden düşük olduğu için regresyon katsayılarının tümünün sıfir olduğu hipotezi reddedilerek en az bir bağımsız değişkenin bağımlı değişken üzerinde etki sahibi olduğu sonucu elde edilir. 
Çoklu regresyon modelinde kurulmuş olan değişkenler arası ilişkilerde bağımsız değişkenlerin kendi aralarında çoklubağlant problemi olup olmadığının teşhisi için Tolerans ve VIF değerleri kontrol edilmiştir. Hesaplanan Tolerans ve VIF değerlerine ilişkin veriler Çizelge 6'da verilmiştir:

Çizelge 6: Çoklu Bağlantı Problemi Teşhisi için Tolerans ve VIF Değerleri

\begin{tabular}{|c|c|c|c|c|c|c|}
\hline \multirow{2}{*}{\multicolumn{2}{|c|}{$\begin{array}{l}\text { (a) } \\
\text { TM Puanları } \\
\text { Model }\end{array}$}} & \multicolumn{5}{|c|}{ (b) TS Puanları } \\
\hline & & Tolerans & VIF & Model & Tolerans & VIF \\
\hline Sabit & & & & Sabit & & \\
\hline Log (1+Eğitim) & ,627 & 1,594 & & Gelir ve Servet & ,430 & 2,323 \\
\hline Log (1+Altyapı) & ,616 & 1,623 & & Eğitim & ,439 & 2,280 \\
\hline Log (1+Yasam_Mem) & ,965 & 1,037 & & Log (Altyapı) & ,488 & 2,051 \\
\hline
\end{tabular}

VIF değerlerinin 10'un altında olması çoklu bağlantı problemi olmadığına işaret etmektedir (Alpar, 2011; Çokluk, vd., 2016; Tabachnick ve Fidel, 2013). Böylece Çizelge 6'da verilen analiz sonuçlarına göre VIF değerinin ölçümüne dayalı çoklu bağlantı problemi olmadığı sonucu elde edilmiştir. Çalışmada çoklu bağlantının olup olmadığının tespiti için ayrıca Koşul indeksine de bakılmıştır. Koşul indeksi, analizine ilişkin veriler Çizelge 7'de verilmiştir.

Çizelge 7: Çoklu Bağlantı Problemi Teşhisi İçin Koşul İndeksine İlişkin veriler

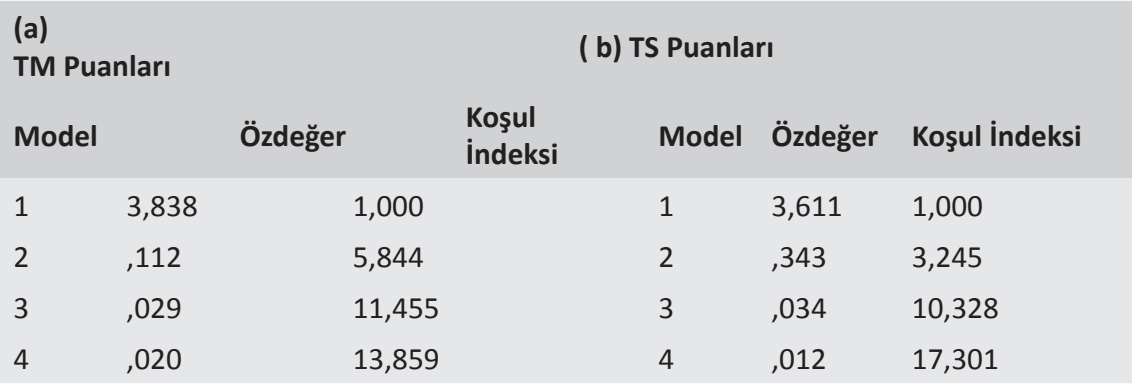

Çizelge 7'ye göre kurulan doğrusal regresyon modelindeki bağımsız değişkenlerin korelasyon matrisinin özdeğerleri ve bu özdeğerlere ilişkin koşul indeksleri verilmiştir. Koşul indeksi değerleri 30'un altında olduğunda bağımsız değişkenler arasında doğrusal bağımlılık ilişkisi olmamaktadır (Alpar, 2011; Çokluk, vd., 2016; Tabachnick ve Fidel, 2013). Çizelge 7'de görüldüğü gibi modelde kullanılan bağımsız değişkenlere ait koşul indeksi değerlerinin hepsi 30'un altındadır. Böylece değişkenler arasında koşul indeksi ölçümlerine göre de çoklu bağlantı problemi yoktur.

Kurulan regresyon modellerinde otokorelasyon problemi olup olmadığının araştırılması da modelin anlamlılı̆ının testi için önem arz etmektedir. Çizelge 8'de otokorelasyon probleminin teşhisi için yapılan Durbin Watson testi sonuçları yer almaktadır: 
Çizelge 8: Otokorelasyon Problemi teşhisi için Durbin Watson Testi Sonuçları

\begin{tabular}{llllll} 
Model & R & R Kare & $\begin{array}{l}\text { Ayarlanmış } \\
\text { Rkare }\end{array}$ & $\begin{array}{l}\text { Tahminin } \\
\text { Standart Hatası }\end{array}$ & $\begin{array}{l}\text { Durbin } \\
\text { Watson }\end{array}$ \\
\hline TM puanları &, 838 &, 702 &, 691 &, 00848893 & 1,826 \\
TS Puanları &, 788 &, 621 &, 607 &, 00715864 & 1,904 \\
MF Puanları &, 742 &, 551 &, 545 &, 01303927 & 1,674
\end{tabular}

Çizelge 8'de üç model için de Durbin Watson test istatistikleri verilmiştir. TM ve TS puanları için $n=81$ ve bağımsız değişken sayısı $k=3$ olarak ele alındığında \% 95 güven düzeyindeki Durbin Watson kritik değerleri tablosuna göre $\mathrm{dl}=1,57$ ve $\mathrm{du}=1,72 \mathrm{dir}$. Her iki model için de Durbin Watson test istatistiği olan sayılar du ve 4-du arasındadır. MF puanları için oluşturulan üçüncü modelde $n=81$ ve $k=1$ için $\% 95$ güven düzeyindeki Durbin Watson kritik değerleri tablosuna göre $\mathrm{dl}=1,62$ ve $\mathrm{du}=1,66^{\prime}$ dır. Durbin Watson test istatistiği 1,674 sayısı du ile 4-du arasında olduğundan bu modelde de otokorelasyon problemi yoktur. (Sastedt Mooi, 2014: 217; Alpar, 2011: 537).

Tüm bu analizler neticesinde modelin anlamlılığının ölçüldüğü $t$ ve $F$ testleri ile çoklu bağlantılı olma durumunun test edildiği VIF ve Koşul İndekslerinin hesaplanarak uygunluk durumunun değerlendirilmesi sonucunda araşttrmanın $\mathrm{H} 1$ hipotezi kabul edilmiştir. Yani çalışma kapsamında bağımlı ve bağımsız değişkenler arasında kurulan ve eşitlik (4), (5) ve (6) da verilen doğrusal modellerin istatistiksel olarak anlamlı olduğu sonucu elde edilmiştir.

\section{TARTIŞMA SONUÇ VE ÖNERILER}

Çalışmada ele alınan bağımlı değişkenler üzerinde etkili olduğu belirlenen bağımsız değişkenlerin her bir puan türünde farklı oldukları görülmüştür. Öncelikle öğrencilerin LYS puanları üzerinde etkisi olduğu görülen yaşanan kente ilişkin 4 değişkenin alt göstergeleri aşağıda verilmiştir:

Gelir ve servet: Kişi başına düşen tasarruf mevduat, orta ve üstü gelir grubundaki hanelerin oranı, temel ihtiyaçlarını karşılayamadığını beyan eden hanelerin oranı.

Eğitim: Üç ve beş yaş aralığını kapsayan okul öncesi eğitimdeki okullaşma oranı, TEOG (Temel Eğitimden Ortaöğretime Geçiş Sınavı) sistemi yerleştirmeye esas puan ortalamaSI, YGS Puan ortalaması, fakülte veya yüksekokul mezunlarının oranı, kamunun eğitim hizmetlerinden memnuniyet oranı.

Yaşam memnuniyeti: Mutluluk düzeyi.

Altyapı Hizmetlerine Erişim: İnternet abone sayısı(yüz kişide), kanalizasyon ve şebeke suyuna erişim oranı, havalimanına erişim oranı, belediyenin toplu taşıma hizmetlerinden memnuniyet oranı.

Bu dört değişkene ilişkin bileşenler incelenirse okul başarısında etkisi olan sayısallaştrılmış sosyal değişkenler ortaya çıkmaktadır. Gelir ve servet değişkeninin bileşenleri kent sakinlerinin sosyoekonomik yapısına ilişkin bilgiler vermektedir. Eğitim değişkeni kent sakinlerinin sosyo kültürel yapısına ve sosyal sermayesine ilişkin bilgiler içermektedir. Altyapı hizmetlerine erişim değişkeni kente merkezi ve yerel kaynaklardan sunulan 
imkânlar hakkında bilgiler içermektedir. Yaşam memnuniyeti değişkeni ise kent sakinleri üzerinde yapılan mutluluk düzeyi anketleri ile belirlenen kişilerin algıları ile ilgili bilgiler vermektedir.

\subsection{Gelir ve Servet Değişkenin Etkisine İlişkin Tartışmalar:}

Araştırmadan elde edilen sonuçlara göre gelir ve servet değişkeni TS öğrencilerinin LYS puanları üzerinde etkilidir. TS puanları lisedeki Türkçe-Sosyal alanı öğrencilerinin üniversiteye girişte kullandıkları puan türüdür. Bu öğrenciler 10. Sınıfta, yani lisenin ikinci yılında yaptıkları alan tercihi sonucunda Türkçe-Sosyal alanına girmiştir. TS alanı matematik ve fen derslerinin olmadığı, genellikle tarih, coğrafya, felsefe, sosyoloji gibi özel derslerle desteklenmesi pek de gerekmeyen derslerin yer aldığı bir alandır. Lisedeki alan seçiminde sosyoekonomik düzeyi düşük olan yoksul öğrencilerin TS alanını tercih ettikleri ya da tercih etmek zorunda kaldıklarına ilişkin çeşitli görüşler vardır. Gelir ve servet değişkeninin TS puanları üzerinde etkili olması bu öğrencilerin önündeki önemli bir sorun olarak yoksulluğun bulunması ile açıklanabilir. Maslow'un temel ihtiyaçlar hiyerarşisine göre üst düzey ihtiyaçların karşılanması için öncelikle barınma-beslenme gibi daha alt düzey ihtiyaçların karşılanması gerekmektedir. TS öğrencilerinin, üst gelir gruplarına ait olarak görülen ve teşvik edilen, fen ve matematik derslerindeki başarısızlıkları sonucu ilgi ve yeteneklerinin sözel derslere kaydığı böylece fen ve matematik alanındaki derslerdeki başarısızlığın kendini gerçekleştiren kehanete dönüştüğü söylenebilir. Böylece yoksul ve alt gelir gruplarından ailelerin çocuklarının bu alanları tercih ettiği varsayımı kuvvetle muhtemeldir.

Gelir ve servet değişkeninin alt göstergeleri kişibaşına düşen mevduat oranı, orta ve üst gelir grubundaki hanelerin oranı, temel ihtiyaçlarını karşılayamadığını beyan eden ailelerin oranıdır. Bir kentte kişibaşına düşen mevduat oranı, o kentteki ailelerin ortalama tasarruflarını göstermektedir, bu değerin yüksek olması kentin gelir durumunun ortalama yüksekliğine işaret eder. Benzer olarak endeksteki orta ve üst gelir grubundaki hanelerin oranının yükselmesi ve temel ihtiyaçlarını karşılayamadığını beyan eden aile oranlarının az olması ${ }^{1}$ kentin ortalama gelir düzeyine ilişkin veriler sağlamaktadır. Kentin ortalama gelir düzeyinin yüksek olması TS öğrencilerinin başarısını arttırmaktadır.

\subsection{Eğitim Değişkeninin Etkisine ilişkin Tartışmalar:}

Eğitim değişkeni her üç puan türündeki başarıda etkili olmaktadır. Bu durum eğitim değişkeninin alt değişkenlerinin öğrencilerin öncel yaşamlarındaki eğitim düzeylerindeki sınav başarılarına ilişkin veriler (TEOG ve YGS) içermesi, ayrıca ailelerinin eğitim düzeyine ilişkin veriler (Fakülte ve yüksekokul mezuniyet oranı) içermesi ile açıklanabilir. Bu ikisi dışında diğer alt değişkenler okul öncesi eğitim basamağındaki okullaşma oranı ve kamunun eğitim hizmetlerinden memnuniyet oranıdır.

Bu sonuçlara göre Türkiye'de zorunlu olmayan okul öncesi eğitim almanın LYS puanları üzerindeki olumlu etkisinden bahsedilebilir. Bunun arka planında ise çalışan anne yani dolayısıyla sosyoekonomik statüsü yüksek olan anneler olabilir.

1 illerde Yaşam Endeksindeki "temel ihtiyaçlarını karşılayamadığını beyan eden ailelerin oranı" gibi endeks değerine olumsuz katkı yapacak olan göstergelerin katsayısı negatif olarak alınarak bu etki pozitife döndürülmüştür. Dolayısıyla olumsuz göstergelerin oranının artması değil, azalması endekse pozitif etki etmektedir. 
Fakülte ve yüksekokul eğitimi kişilere daha nitelikli işler sağlayıp bir yandan da onların kültürel sermayesine katkı sağlamaktadır. Böylece üniversite mezunu ailelerin çocuklarının her üç alanda da başarısı artmaktadır.

Kamunun eğitim hizmetlerinden memnuniyet oranı bu hizmetlerden nispeten yararlanabilen kişi sayısının yani sosyal ve toplumsal kurumlardan dışlanmayan (sosyal dışlanma) kişi sayısının çokluğuna işaret eder. Bu durum da kentteki ortalama yaşamın kalitesinin yüksekliği ile ifade edilebilir.

\subsection{Yaşam Memnuniyeti Değişkeninin Etkisine İlişkin Tartışmalar:}

Yaşam memnuniyeti değişkeni TM öğrencilerinin aldığı LYS puanları üzerinde etkilidir. TM puanları Matematik ve Türkçe ağırlıklı puanlar olup bu puan türü ile tercihte bulunacak olan yani lise eğitiminin ikinci yılı olan 10. Sınıfta Türkçe-Matematik Alanını seçip bu alandan üniversiteye girmeyi hedefleyen öğrencilerin kullandığı bir puan türüdür. Bu öğrenciler lise eğitimlerinin son üç yılında ağılıklı olarak bu alandan dersler almışlardır. Eğer lisedeki alan tercihlerinin bu alandaki ilgi ve yeteneklerini yordamış olduğuna ilişkin bir varsayım kabul edilirse bu puan türü ile tercih yapacak öğrencilerin matematiksel becerilerinin yanısıra çoğunlukla sosyal yönleri de güçlü olan toplumsal çevre ile ilgilenen bireyler olduğundan hareket edilebilir. Bu bireylerin okul başarısında çevrelerinde kendisini mutlu olarak algılayan bireylerin oranının yükselmesi onların kendi algılarını da etkilemiş ve başarıları üzerine olumlu etki göstermiştir.

\subsection{Altyapı Hizmetlerine Erişim Değişkeninin Etkisine iliş̧̧in Tartışmalar:}

Altyapı hizmetlerine erişim değişkeni TM ve TS puan türlerindeki başarı üzerinde etkili olmaktadır. TM ve TS puan türlerindeki öğrencilerin ortak yönleri ortak aldıkları sözel derslerle şekillenmektedir. Bu dersler ise Türkçe, Edebiyat ve Dil Anlatım, Felsefe, Coğrafya, Tarih, Psikoloji, Demokrasi ve İnsan Hakları gibi derslerdir. Ayrıca okuldaki öğretmen kapasitesine bağlı olarak Mantık, Bilgi Kuramı, Sosyoloji, Türk Kültür ve Medeniyet Tarihi, İslam Bilim Tarihi, Çağdaş Türk ve Dünya Tarihi, İşletme Ekonomi, Girişimcilik, Yönetim Bilimi, Uluslararası illişkiler gibi dersler de alabilmektedirler (MEB, 2017). Bu öğrencilerin de sosyal çevrelerine duyarlı, sosyal çevrelerindeki politikanın bir sonucu olarak kamu hizmetlerinin sunumuna duyarlı olmaları beklenen bir durumdur. Bu değişken internet abone sayısı, kanalizasyon ve şebeke suyuna erişim oranı, havalimanına erişim oranı, belediyenin toplu taşıma hizmetlerinden memnuniyet oranı alt değişkenlerini içermektedir. Bu alt değişkenlerdeki artış bu öğrencilerin başarısında etkili olmuştur.

\subsection{Doğrusal Modele Etkisi Olmayan Değişkenlere Iilişkin Tartışmalar:}

Analizler sonucunda 11 değişkenden oluşan Illlerde Yaşam Memnuniyeti endeksindeki diğer 7 değişkenin öğrencilerin LYS Puanları üzerinde istatistiksel olarak anlamlı doğrusal bir model oluşturacak bir ilişkisi olmadığı bulunmuştur. Bu yedi değişken ise şunlardır:

Konut: Kişi başına düşen oda sayısı, evde tuvalet bulunan hanelerin oranı, evin kalitesinde sorun yaşayanların oranı

Çalışma Hayat: İstihdam oranı, işsizlik oranı, ortalama günlük kazanç, işinden memnuniyet oranı,

Sağlık: Bebek ölüm hızı, doğuşta beklenen yaşam süresi, hekim başına düşen müraca- 
at sayısı, sağ|ı̆̆ından memnuniyet oranı, kamunun sağlık hizmetlerinden memnuniyet oranı

Çevre: PM10 İstasyon değerleri ortalaması(hava kirliliği), km2'ye düşen orman alanı, atık hizmeti verilen nüfusun oranı, sokaktan gelen gürültü problemi yaşayanların oranı, belediyenin temizlik hizmetlerinden memnuniyet oranı

Güvenlik: cinayet oranı (bir milyon kişide), ölümlü ve yaralanmalı trafik kazası sayısı (bin kişide, gece yalnız yürürken kendini güvende hissedenlerin oranı, kamunun asayiş hizmetlerinden memnuniyet oranı

Sivil katlım: Mahalli idareler seçimlerine katılım oranı, siyasi partilere üyelik oranı, sendika/dernek faaliyetleri ile ilgili olanların oranı

Sosyal Yaşam: Sinema ve tiyatro seyirci sayısı (yüz kişide), bin kişi başına düşen alışveriş merkezi alanı, sosyal ilişkilerinden memnuniyet oranı, sosyal hayatından memnuniyet oranı

Bu araştırmadan elde edilen bulgulara göre bu 7 değişkenin öğrencilerin LYS puanlarını etkilemediği söylenemez. Sadece bu değişkenlerle öğrencilerin LYS puanları arasında doğrusal matematiksel bir model oluşturacak bir ilişki olmadığı söylenebilir. Zaten yukarıda verilmiş olan ilgili nitel araştırmalar sayısal olarak ifade edilemeyen pek çok değişkenin okul başarısındaki etkisini göstermiştir.

\subsection{Sonuçlar ve Öneriler}

$\mathrm{Bu}$ araştrrmada kentlere ilişkin veriler kenti betimleyen göstergelerle ifade edilmiştir. illerde Yaşam Endeksi bireylerin ve hanehalkının yaşamını objektif ve bireylerin öznel algıları gibi sübjektif ölçütler kullanarak her ilde yaşayanların yaşam kalitesini ölçmeyi amaçlayan bir göstergedir. ${ }^{2}$ illerde Yaşam Endeksi 11 boyut altında toplam 41 göstergeden oluşmaktadır: Çizelge 3'te de verilmiş olan, hesaplanan endeks değerlerine göre en üst sıradaki ilk 5 il: Isparta, Sakarya, Bolu, Kütahya, İstanbul'dur. Liste sondan başlanarak okunursa Muş, Mardin, Ağrı, Şırnak Batman olarak Endeksin sonundaki sıralama görülür.

Bu araşttrmada sosyo ekonomik ve sosyo kültürel göstergelerin başarı üzerinde etki ettiğine ilişkin yapılmış olan pek çok araştırma ile benzer bulgular elde edilmiştir. Araştırmanın yöntemi olarak seçilmiş olan çok değişkenli doğrusal regresyon analizinin ve bu analizin bir parçası olarak logaritmik dönüşümlerin kullanılmasının, sosyal olayları etkileyen pekçok değişkenin bir arada analiz edilmesini sağladığı, böylece sosyal gerçekliğin açıklanmasına katkı sağladığı görülmüştür.

Araştırma sonuçları yaşanılan mekânın insan yaşamının kalitesi üzerinde yapacağı etkiye ilişkin çeşitli göstergelerin iyileştirilmesinin başarıya olumlu katkısının olacağını göstermektedir. Kentteki gelir ve servete ilişkin alt değişkenler olarak kişi başına düşen tasarruf mevduatının; orta ve üstü gelir grubundaki hanelerin oranının arttrılmasının, temel intiyaçlarını karşılayamayan hanelerin oranının azaltılması yönünde üretilecek politikaların o kentteki öğrencilerin başarısı üzerinde olumlu etkisi olacaktır. Tasarruf mevduatının arttıılması demek hanelerin kendi geçimlerini sağlayacak maddi kaynakları elde

2 TÜiK, OECD’nin Daha İyi Yaşam Endeksi'ni baz alarak yaptı̆ı İllerde Yaşam Endeksinin ikinci yayınını 2017 de, bundan sonrakileri de her üç yılda bir yapacağını açıklamıştır. 
ettikten sonra arttırması, yani ihtiyacından çok kazanması anlamına gelmektedir. Bu durum mümkün olmadığında gerek geçim sağlanamamakta gerekse hanenin okula devam eden çocuğunun başarısı düşmektedir. Okul öncesi eğitimdeki okullaşma oranının arttrılmasının, TEOG sistemindeki puan ortalamasının, YGS puan ortalamasının, fakülte ve yüksekokul mezunlarının oranının arttırılmasının, kamunun eğitim hizmetlerinden yararlananların ve bundan memnun olanların oranının arttırımasının öğrencilerin okul başarısı üzerinde olumlu etkileri olacaktır.

Kentte internet erişim oranının arttırılmasının, belediyenin toplu taşım hizmetlerinin kalitesinin arttııımasının, bu hizmetlerden yararlananların memnuniyet düzeyinin yükseltilmesinin kanalizasyon ve şebeke suyuna erişim oranı ile havalimanına erişim oranının yükseltilmesinin öğrencilerin okul başarılarına olumlu etkisi olacaktır. Dolayısıyla gerek yerel yönetimlerce gerekse merkezi yönetim tarafindan yapılacak hizmetlerin ve bu hizmetlerin kalitesinin arttrılması o kentin öğrencilerinin başarısının arttırımasını sağlayacaktır.

Kentteki insanların mutluluk düzeyinin arttıılmasının öğrencilerin ailelerinde ya da çevrelerinde mutlu insanları görmelerinin okul başarısına olumlu etkisi olacaktır. Mutluluk algılanan ve öznel olan bir kavramdır. Ancak temel ihtiyaçların karşılanması, sosyal ve ekonomik kurumlardan dışlanmama, bir gruba ya da topluluğa aidiyet duygusu taşıma, eşitsizliğe ve adaletsizliğe uğramış hissine sahip olmama ve nihayetinde kendi ideal ve amaçlarına ulaşma-kendini gerçekleştirebilecek potansiyele sahip olma gibi somut olarak ifade edilebilen bir altyapısı vardır. Yurttaşlara tüm bunları gerçekleştirebilecekleri bir potansiyelde yaşama firsatının sağlanması, yaşam kalitesini yükseltecek, toplumun algıladığı mutluluk düzeyini yükseltecek ve dolayısıyla öğrencilerin başarı düzeyini yükseltecektir.

Bu sonuçlar sosyo ekonomik ve sosyo kültürel pek çok değişkenin öğrenci başarısı üzerinde etkisi olduğunu göstermektedir. Başarı sadece okul içi süreçlere kısıtlanamaz. Okulun ait olduğu topluma ilişkin pek çok sosyal değişkenin okuldaki başarıyı arttıracak etkisi vardır. LYS sonuçları açıklandığında en başarılı-başarısız iller ifade edilirken, bu olayın nedenleri, sonuçları ve çözülmesi için gereken politika önerileri de gündeme getirilmelidir. Eğitimcilerin, eğitime ilişkin politika yapıcıların ve eğitim alanıyla ilgili alanlarda karar verici pozisyonlarda çalışan yöneticilerin, başarıyı arttırmaya dönük ilke ve hedefleri belirlerken, yaşanılan kentteki yaşam kalitesini yükseltici unsurları da iyileştirmeye dönük politikaları ve politika önerilerini de içerecek geniş bir perspektiften durumu ele almaları öğrenci başarının arttırılmasında etkili olacaktır. 


\section{KAYNAKÇA}

Alpar, R. (2011). Çok Değişkenli İstatistiksel Yöntemler. Ankara: Detay Yayıncılık.

Anıl, D. (2009). Uluslararası Öğrenci Başarılarını Değerlendirme Programı’nda (PISA) Türkiye'deki Öğrencilerin Fen Bilimleri Başarılarını Etkileyen Faktörler. Eğitim Bilim. Cilt 34. Sayı152. ss.87-100.

Apple, M.(2006). Eğitim ve Iktidar. İstanbul: Kalkedon Yayınları

Bahar, H.H. (2010). The Effects of Gender, Perceived Social Supportand Socioeconomic Status on Academic Success. Procedia Social and Behavioral Sciences Vol: 2. pp. 3801-380.

Balcı, A. (2005). Açıklamalı Eğitim Yönetimi Terimleri Sözlüğü. Ankara: Tekağaç Yayınevi.

Büyüköztürk, Ş., Kılıç Çakmak, E., Akgün, Ö. E., Karadeniz, Ş., \& Demirel, F. (2013). Bilimsel Araşttrma Yöntemleri. Ankara: Pegem Akademi.

Can, A. (2017). SPSS ile Bilimsel Araştrrma Sürecinde Nicel Veri Analizi. 5. Baskı. Ankara: Pegem Akademi.

Coleman, J.S. (1966). Equality of Educational Opportunity. Washington: U.S. Government Printing Office.

Clark, R. (1993). Homework-Focused Parenting Practices That Positively Affect Student Achievement. In Chavkin, Nancy Feyl (Ed.), Families and Schools in a Pluralistic Society Albany, NY: State University of New York Press, pp. 85-105.

Clark, R. (2002). Ten hypotheses about what predicts student achievement for African American students and all other students: What the research shows, in Walter R. Allen, Margeret Beale Spencer, Carla O'Connor (ed.) African American Education: Race, Community, Inequality, and Achievement a Tribute to Edgar G. Epps (Advances in Education in Diverse Communities: Research, Policy and Praxis, Volume 2). Emerald Group Publishing. pp.155 - 177.

Creswell, J.W. (2003). Nitel araştırma Yöntemleri. (Çeviri Editörleri: Mesut Bütün, Selçuk Beşir Demir). Ankara: Siyasal Kitabevi.

Çokluk, Ö., Şekercioğlu G., Büyüköztürk, Ş. (2016). Sosyal Bilimler İ̧̧in Çok Değişkenli i̇statistik SPSS ve Lisrel Uygulamaları.4. Baskı. Ankara: Pegem Akademi.

Dağlı, S. (2014).KPSS Eğitim Bilimler Öğretim Yöntem ve Teknikleri. www.gelecekrehberi.net. Adresinden 24.11.2017 tarihinde alınmıştır.

Everheart, R. B. (1983). Reading, Writing and Resistance: Adolescence and Labor in a Junior High School. Boston: Routledge Publications.

Gelbal, S. (2008). Sekizinci Sınıf Öğrencilerinin Sosyoekonomik Özelliklerinin Türkçe Başarısı Üzerinde Etkisi. Eğitim ve Bilim. Vol:33.No:150.ss.1-13.

Heyneman, S.P. ve Loxley, W. (1983). The Distribution of Primary School Quality within High- and Low-Income Countries. Comparative Education Review. Vol:27(1). pp.108-118.

Hoffman, K., Llagas, C. \& Snyder, T.D.(2003). Status and Trends in the Education of Blacks. National Center for Education Statistics. https://nces.ed.gov/pubs2003/2003034.pdf Adresinden 01.11.2017 tarihinde alınmıştir.

Jencks, C., Smith, M., Acland, H., Bane, M., Cohen,D., Gintis, H., Heyns,B. \& Michelson, S.(1973). Inequality: A Reassessment of the Effect of Family and Schooling in America.American Journal of Sociology.Vol:78 (6). pp.1523-1544.

Katzman, M. T. (1971). The Political Economy of Urban Schools. Cambridge: Harvard University Press.

Köksal, O. ve Atalay, B.(2015). Öğretim İlke ve Yöntemleri. Eğitim Yayınevi.

Kurul, N. (2002). Öğrenci Başarısında Etkili Okul Değişkenleri ve Eğitimde Verimlilik. Ankara Üniversitesi Eğitim Bilimleri Fakültesi Dergisi. Cilt 35. Sayı: 1-2.ss. 39-54.

McLaren, P. (2003). Life in Schools: An Introduction to Critical Pedagogy. Boston: Pearson Education.

McRobbie, A. (1978).Working Class Girls and the Culture of Femininity. Women Take Issue. pp.96-108.

MEB (2017). Ortaöğretim Kurumları Haftalık Ders Programları. http://ttkb.meb.gov.tr/www/haftalik-derscizelgeleri/kategori/7 Adresinden 01.07.2017 tarihinde alınmıştr.

Menard, S. (2010). Logistic Regression: From Introductory to Advanced Concepts and Applications. California: Sage Publications.

Mertler, C.A. \& Vannata, R.A. (2005). Advanced and Multivariate Statistical Methods: Practical Application and Interpretation. Grendale. CA: Pyrczak Publishing.

Montgomery, D.C., Peck, E. \& Vinning, G.G. (2013). Doğrusal Regresyon Analizine Giriş. Çeviri Editörü: M. Aydın Erar. Ankara: Nobel Yayınevi.

OSYM (2013a). 2013 Lisans Yerleştirme Sınavı Sonuçları.

OSYM (2013b). Ortaöğretim Kurumlarına Göre 2013 Öğrenci Seçme ve Yerleştirme Sistemi Sonuçları Kitabı. 
OSYM (2014a). 2014 Lisans Yerleştirme Sınavı Sonuçları.

OSYM (2014b). Ortaöğretim Kurumlarına Göre 2014 Öğrenci Seçme ve Yerleştirme Sistemi Sonuçları Kitabı. OSYM (2015a). 2015 Lisans Yerleştirme Sınavı Sonuçları.

OSYM (2015b). Ortaöğretim Kurumlarına Göre 2015 Öğrenci Seçme ve Yerleştirme Sistemi Sonuçları Kitabı. OSYM (2016a). 2016 Lisans Yerleştirme Sınavı Sonuçları.

OSYM (2016b). Ortaöğretim Kurumlarına Göre 2016 Öğrenci Seçme ve Yerleştirme Sistemi Sonuçları Kitabı. Parasız i. (2014). İtisada Giriş. Ezgi Kitabevi.

Pokropek, A., Borgonovi, F. ve Jakubowski, M. (2015). Socio-Economic Disparities in Academic Achievement: A Comparative Analysis of Mechanisms and Pathways. Learning and Individual Differences Vol.42. pp. $10-18$

Sanjurjo, S. F., Blanco, J.M.A ve Costales, A.F. (2017). Assessing the Influence of Socio-Economic Status on Students' Performance in Content and Language Integrated Learning. System. In Press.http://dx.doi. org/10.1016/j.system.2017.09.001.

Sasttedt,M., Mooi, E. (2014). A Concise Guide to Market Research: The Process Data and Methods Using IBM Statistics. London: Springer

Sarıer, Y. (2016). Türkiye'de Öğrencilerin Akademik Başarısını Etkileyen Faktörler: Bir Meta-Analiz Çalışması. Hacettepe Üniversitesi Eğitim Fakültesi Dergisi. 31(3). ss. 609-627.

Sayılan, F. ve Ozkazanç, A. (2008). Gendered Power Relations in the School: Construction of Schoolgirl Femininities in a Turkish High School. International Journal of Social Sciences, vol.3, n.1.pp.1-12.

Tabachnick, B.G. ve Fidel, L.S. (2013). Using Multivariate Statistics. Boston MA: Pearson.

Taşpınar, M. (2012). Kuramdan Uygulamaya Öğretim İlke ve Yöntemleri. Ankara: Pegem

TDK (2016). Güncel Türkçe Sözlük. http://www.tdk.gov.tr/ Adresinden 10.01.2017 tarihinde alınmıştr.

TÜiK (2016). illerde Yaşam Endeksi. Haber Bülteni. Sayı: 24561. Açıklanma Tarihi: 22 Ocak 2016.

Yıldırım, ì. (2006). Akademik Başarının Yordayıcısı Olarak Gündelik Sıkıntılar ve Sosyal Destek. Hacettepe Üniversitesi Eğitim Fakültesi Dergisi. 30 .ss.258-267.

Willis, P. (1977): Learning to Labor: How Working Class Kids Get Working Class Jobs. New York: Columbia University Press. 